\title{
Challenging conventional mindsets and disconnects in conservation: \\ The emerging role of ecoagriculture in Kenya's landscape mosaics
}

Thomas Yatich, Wahida Patwa Shah, Joseph Mutua, Joseph Tanui, David Kuria, Mwangi Githiru, Wanja Kinuthia, John Waithaka, Ikonye Njoroge 



\section{Challenging conventional mindsets and disconnects in conservation: The emerging role of ecoagriculture in Kenya's Landscape Mosaics}

Thomas Yatich, Wahida Patwa Shah, Joseph Mutua, Joseph Tanui, David Kuria, Mwangi Githiru, Wanja Kinuthia, John Waithaka, Ikonye Njoroge 


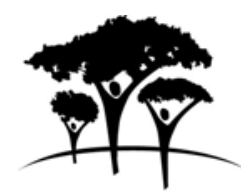

World Agroforestry Centre

TRANSFORMING LIVES AND LANDSCAPES

Correct citation: Yatich T, Patwa Shah W, Mutua J, Tanui J, Kuria D, Githiru M, Kinuthia W, Waithaka J, Njoroge I. 2009. Challenging conventional mindsets and disconnects in conservation: The emerging role of ecoagriculture in Kenya's Landscape Mosaics. ICRAF Working Paper no. 83. Nairobi, Kenya: World Agroforestry Centre.

Titles in the Working Paper Series aim to disseminate interim results on agroforestry research and practices and stimulate feedback from the scientific community. Other publication series from the World Agroforestry Centre include: Agroforestry Perspectives, Technical Manuals and

Occasional Papers.

Published by the World Agroforestry Centre

United Nations Avenue

PO Box 30677, GPO 00100

Nairobi, Kenya

Tel: +254(0)20 7224000, via USA +16508336645

Fax: +254(0)20 7224001, via USA +1 6508336646

Email: icraf@cgiar.org

Internet: www.worldagroforestry.org

(C) World Agroforestry Centre 2009

ICRAF Working Paper no. 83

The views expressed in this publication are those of the author(s) and not necessarily those of the World Agroforestry Centre.

Articles appearing in this publication may be quoted or reproduced without charge, provided the source is acknowledged. No use of this publication may be made for resale or other commercial purposes. All images remain the sole property of their source and may not be used for any purpose without written permission of the source.

The geographic designation employed and the presentation of material in this publication do not imply the expression of any opinion whatsoever on the part of the World Agroforestry Centre concerning the legal status of any country, territory, city or area or its authorities, or concerning the delimitation of its frontiers or boundaries. 


\section{Contributors}

Thomas Yatich, World Agroforestry Centre (ICRAF)

Wahida Patwa Shah, World Agroforestry Centre (ICRAF)

Joseph Mutua, Kenya Network for Dissemination of Agricultural Technologies (KENDAT)

Joseph Tanui, Africa Highlands Initiative, Uganda

David Kuria, Kijabe Environment Volunteers (KENVO)

Mwangi Githiru, National Museums of Kenya (NMK)

Wanja Kinuthia, National Museums of Kenya (NMK)

John Waithaka, Kenya Nut Company Limited

Ikonye Njoroge, Greenbelt Movement, Kenya

\section{Abstract}

Innovative approaches such as ecoagriculture that integrate increased agricultural productivity, ecosystem conservation and improved rural livelihoods in the face of declining land sizes, land use changes and increase in population are visualized as providing opportunities for sustaining resource productivity both for current and future generations. It is hypothesized that agricultural landscapes can be designed more creatively to allow for these multiple functions of agriculture by integrating biodiversity conservation and enhanced ecosystem services management through a number of strategies. This working paper provides a synthesis of the results of this scoping study undertaken in four Kenyan agricultural landscape mosaics (Taita Hills, Ndakaini/Muranga South, Mathioya/Muranga, and Lari) to identify and evaluate ecoagriculture innovations, strategies and activities.

In Kenya like in other East African countries, these practices however, are ad hoc, not readily available to a wider audience and are individual-based. Such innovations continuously evolve but their impacts and constraining factors are seldom documented and localized. The scoping study reveals that ecoagriculture practices are diverse, have been evolving over space and time and thrive because of various motivating factors. Farmers' adoption of particular technologies was basically influenced by returns within a shortterm planning horizon as well as the tradeoffs they have to make. Extension services and facilitation by the government was also cited as inadequate.

The study did not provide an exhaustive measurement of the spatial and temporal spread of those innovations in both agriculturally homogenous and relatively heterogeneous landscapes, however it was found that motivational factors that shape design, adoption, adaptation and implementation of ecoagriculture innovations are influenced by a number of external and internal factors. The results of this study may inform Kenya's Strategy for the Revitalization of Agriculture by pointing to the need for innovative mechanisms for extension service provision, better marketing support and incentives for collective action to increase agricultural productivity, maintain biodiverse landscapes and improve livelihoods of the rural poor. 


\section{Table of Contents}

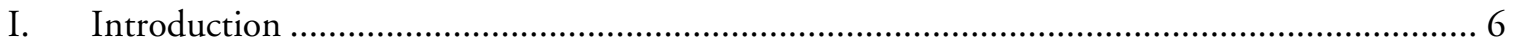

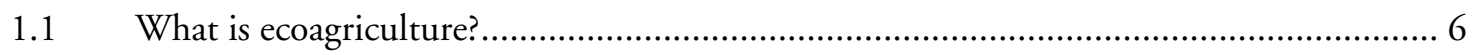

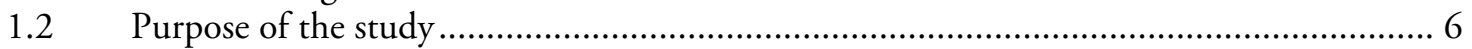

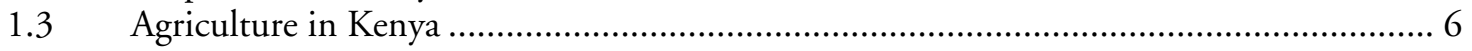

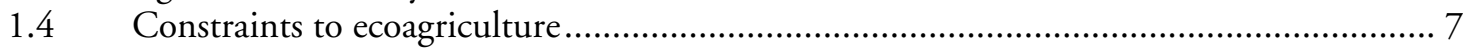

2. Enhancing Biodiversity, Food Security and Rural Livelihoods in Kenya ................................... 8

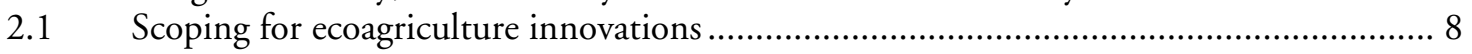

2.2 Conceptual framework for ecoagriculture practices in Kenya ....................................... 11

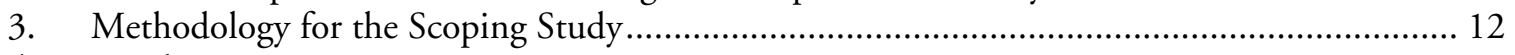

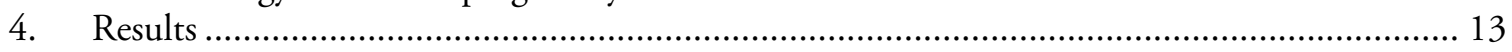

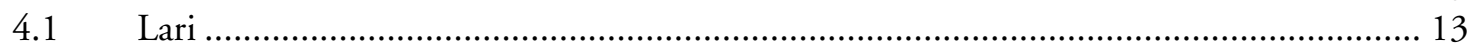

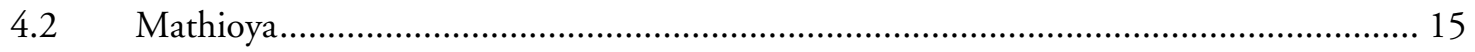

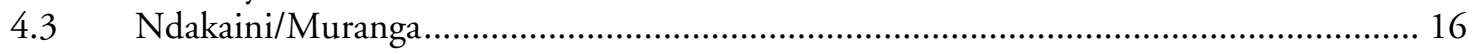

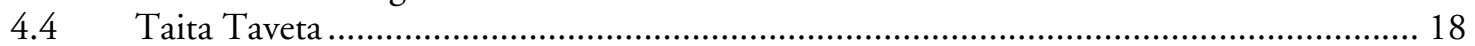

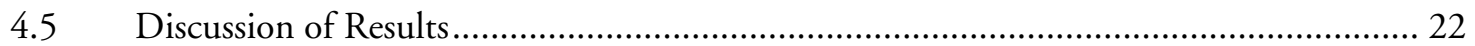

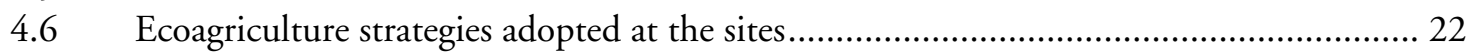

4.6.1 Modifying farming systems to mimic natural systems ....................................... 22

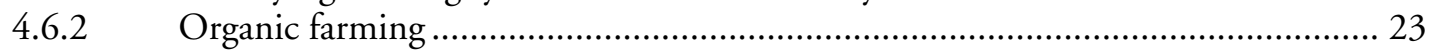

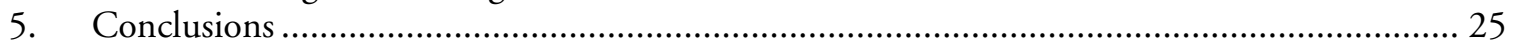

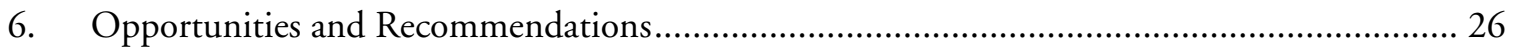

6.1 Market mechanisms and incentives for ecoagriculture approaches ................................ 26

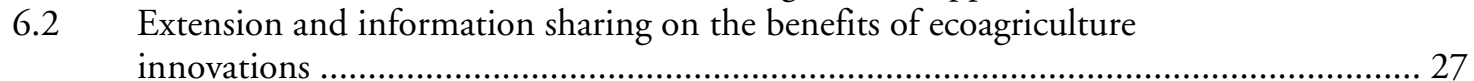

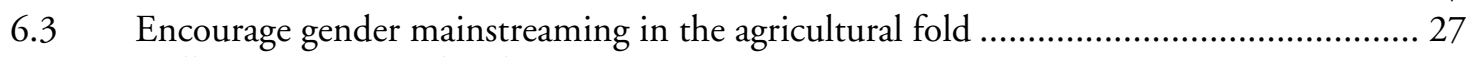

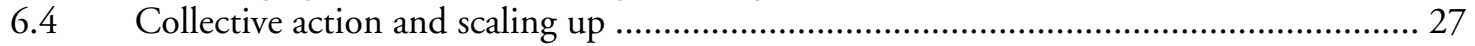

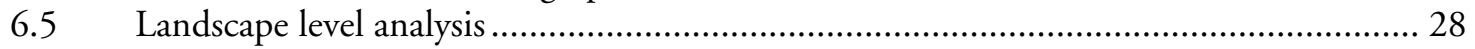

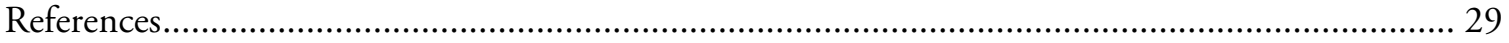




\section{Preface}

At the conclusion of a learning workshop held at Naivasha between 12-18 November 2006 organized by Ecoagriculture Partners in collaboration with The World Agroforestry Centre (ICRAF) and with the University of California, Berkeley, Kenyan participants undertook a study to document agricultural innovations and land use practices that reduce threats to biodiversity, environmental conservation, and land productivity - and at the same time enhance rural livelihoods in Kenya. Additionally they decided to conduct a scoping study of the policy issues and legislative frameworks that influence land use practices and prevent adoption of conservation measures at plot, landscape and national levels.

The participants were organized under the leadership of the Kenya Network for Dissemination of Agricultural Technologies (KENDAT) and received financial help from the ICRAF small grants scheme. It is hoped that the outcomes of this study will help economic planners in developing the necessary tools for implementing some aspects of the economic and social pillars of vision 2030 in Kenya.

\section{Acknowledgements}

The research team would like to acknowledge financial and technical support from Ecoagriculture Partners (EP) and the World Agroforestry Centre (ICRAF) that made the scoping study in different agricultural landscape mosaics possible. We also wish to acknowledge the pivotal role that the different institutional partners played in the implementation of the study. Site-specific research teams are also acknowledged. We wish also to acknowledge James Wachira, Ronald Ngiru, Alice Gikonyo, Purity Muthoni, Nicholus Kinyanjui, Robinson Njoroge, Paul Kamau, Jonam Mwandoe, Nathaniel Mkombola and Bernard Ndungu for the time they spent interviewing farmers in the respective landscape mosaics. 


\section{Introduction}

\subsection{What is ecoagriculture?}

Ecoagriculture seeks to simultaneously achieve improved livelihoods, conservation of biodiversity and sustainable production at a landscape scale. It advocates for the management of agricultural landscapes to ensure sustained supply of food, fibre and other ecosystem services, including biodiversity. Ecoagriculture is promulgated as a framework for achieving the millennium development goals on hunger, poverty alleviation and environmental sustainability (Juma \& Yee-Cheong 2005). The ecoagriculture approach recognizes that agriculture's ecological footprint is large (see for example, Kiers et al. 2008) and furthermore economies are tied to the state of the ecosystems and associated ecosystem services especially in developing countries like Kenya where agriculture is such a critical part of the economy.

\subsection{Purpose of the study}

The Nairobi Declaration (Ecoagriculture Conference 2004) noted that grass root communities and farmers all around the world have practiced ecoagriculture principles for millennia, with the potential for maintaining ecosystems and transforming vast areas of degraded lands and other habitats of high biodiversity value or endangered species. These efforts have however not been documented and disseminated in ways that can be used to influence wider national and regional scaling up.

The implementation of ecoagriculture practices has been by default rather than deliberate effort through organised multi-stakeholder initiatives at a landscape level. Ecoagriculture practices are therefore at the cross roads requiring intervention to ensure that there is deliberate, planned and coordinated effort to systematically design and implement good ecoagricultural practices. Such effort can be informed by well-documented cases of good practices across landscapes in the country, shared and used to influence and shape policy at different scales.

This study aims to provide a snapshot of innovations in agriculture in Kenya that can be termed ecoagriculture innovations. It is hoped that information such as this can contribute to the sharing of knowledge and practice for wider adoption and scaling up of ecoagriculture practices across landscapes.

\subsection{Agriculture in Kenya}

In Kenya, agriculture is the country's mainstay and engine of economic growth accounting for over $50 \%$ of the country's gross domestic product and $80 \%$ of export earnings. It provides employment for $80 \%$ of the population and $70 \%$ of materials for agro-based industrial production, therefore being the main source of livelihood (Republic of Kenya 2004).

Kenya is a world leader in the export of tea, coffee and horticultural products. Kenya's dairy sector is among the best developed in Africa, and the Kenya Highlands comprise one of the continent's most successful agricultural production regions. Both small and large-scale farming make up this sector. The primary food crops for subsistence level production include, cassava, potatoes, maize, sorghum, and fruit. Despite these successes, smallholder farmers in the highlands of Kenya face many constraints; including variability and unreliability of rainfall, degradation of soils and water quality, inadequate mechanisms for water storage, and inadequate financing for purchasing farm inputs and fertilizer. At the meso-scale there is a lack of well-developed markets for many agricultural products and at the national scale, little investment in agriculture and research and development, in relation to the importance of this sector to the economy. The net effect for smallholder farmers is their decreasing ability to invest in measures that will result in increased and long term productivity of their farming systems. 
Kenya, mirroring a global trend, has been affected by the current food crises. This has translated into higher prices for basic commodities. Current problems are caused by a transformation in regards to how and what type of food is consumed (by growth in income and changing diets), high-energy prices, and increased urbanization (Von Braun, 2007). Current challenges include how to meet demand for food, to reduce risks and shocks at the farm level especially for smallholder farmers and to ensure that the resource base upon which food production is dependent is conserved. Depletion and repletion of soil nutrients and other natural resource assets are contingent on poverty dynamics as the farmers' abilities to invest in their environment is determined by their economic status.

In the highlands of Kenya, where smallholder agriculture is concentrated, poverty dynamics depend on the interplay of human and natural systems on the smallholder farms. These poorer farmers operate at the margin and small changes in the natural resource base often have large effects on people's lives. Ecoagriculture approaches within agriculture, involve managing the landscape for both production and the conservation of wildlife and ecosystems (McNeely \& Scherr, 2003). The 2008 World Development Report emphasizes that the future of agriculture is tied intrinsically to better stewardship of the natural resource base while the International Agricultural Assessment of Science and Technology Development (IAASTD) notes that agricultural sustainability means maintaining productivity while protecting the natural resource base. It provides evidence to indicate that although we have made gains in terms of production over the last 50 years worldwide, there has been less attention to social and environmental issues.

\subsection{Constraints to ecoagriculture}

In spite of agriculture being the engine of Kenya's economic growth and the main source of livelihoods for millions of low resource Kenyans, it faces many challenges and constraints ranging from unreliable rainfall, inadequate finance for purchasing farm and other inputs, fragmented land sizes, poor farming skills, pests and diseases, and the lack of markets and marketing infrastructure.

Environmental problems arise from natural calamities such as drought and floods; soil erosion, degradation, infertility, and desertification. Human activities that exacerbate natural problems or create new problems include pollution from point and non-point sources, land use change resulting in deforestation and the destruction of wetlands, which results into further risks; and degrading resources for profitable and sustainable agriculture encroachment and into other land uses, leading to deforestation and negative impacts on wildlife and on pastoralists.

The ecosystems and associated ecosystem services, which underlay agriculture are the wealth of the rural poor (World Resources Institute 2005), but the approaches and the levels of their exploitation result in soil, water quality and land degradation. The net effect of these constraints is poor and low quality harvest which consequently fetches low prices. Therefore, the ability of economically disadvantaged farmers to invest in conservation measures and adopt some tenets of sustainability is significantly reduced. The prognosis for the near future is increased land degradation, which entangles the farmers in a poverty spiral.

Population increases in Kenya, currently estimated at 3\% per year, have created pressure on land, forest and water resources. Due to the high population and urbanization growth rates ${ }^{1}$, land per capita has been sharply declining in high potential areas (NEMA, 2003). Currently Kenya's population density is estimated at more than 60 persons per square kilometer against a shortage of good agricultural land that is only about 1.9 million ha representing a third of the total land area (Mbugua, 2002).

${ }^{1}$ Kenya's State of the Environment Report (NEMA, 2003) put population and urbanization growth rate at 3\% and 6\% respectively 
Increased population pressure, market-and profit-driven land use change and policy failure have affected critical ecosystems. Consequentially cropping has spilled over to arid and semi-arid areas $^{2}$ destabilizing ecosystems' resilience. Biodiversity and other environmental services provided by agricultural landscapes also threatened land use and land tenure changes in savannah grasslands. Parks and reserves are also under pressure from adjacent communities who have decreased access to resources. There is a general failure to recognize communities' role in agrobiodiversity conservation.

Scaling up is an emerging research agenda, with relevance to ecoagriculture practices. Factors causing low adoption rates of natural resource management technologies and approaches are still not fully understood. In Kenya's longer-term Vision $2030^{3}$ a comprehensive diagnostic, robust strategy and detailed action plans to stimulate growth across all key sectors of the economy is being advocated. This requires sustainable agricultural production systems and healthy ecosystems which are currently threatened. If the current 'business as usual' scenarios continue, the state of biodiversity, ecosystems and human well-being would be jeopardized. This therefore requires greater appreciation of ecological processes, links between ecosystems within landscapes, inclusion of livelihood priorities, local knowledge and the possibility for integrated management.

Ecoagriculture cannot address all the constraints that smallholder farmers face, but can provide a framework for incorporating the multiple functions of agriculture, which include maintaining ecosystem services. Innovative practices that could provide lessons for scaling up need to be shared.

\section{Enhancing Biodiversity, Food Security and Rural Livelihoods in Kenya}

\subsection{Scoping for ecoagriculture innovations}

The study explored four sites to ascertain how the multiple objectives of ecoagriculture could be achieved in relation to ecoagriculture strategies discussed by Scherr \& McNeely (2003). These strategies (Scherr \& McNeely 2003:109) include those that augment biodiversity and ecosystem services.

A. Creating biodiversity reserves that benefit local farming communities

- Identifying locally beneficial areas for protection with local communities

- Protecting agricultural habitats

- Enhancing benefits from protected areas for local farmers

B. Develop habitat networks in non farmed areas - finding landscape niches for biodiversity

- $\quad$ Around water resources

- In and around farm fields

- In and around forest areas

- $\quad$ Other sites (homesteads, along roadsides, sacred places or groves, school gardens, agro ecotourism sites, public parks)

C. Reduce land conversion by increasing farm productivity

- Agricultural innovations to increase productivity and sustainability. These issues have to be carefully analysed, for example when increasing productivity provides incentives to farm more land and increase conversions.

${ }^{2}$ Form $80 \%$ of Kenya's land and mainly for livestock keeping with limited agricultural activities.

${ }^{3}$ National Economic and Social Council-based on Dr. Wahome Gikuru’s (Director, NESC) presentation during the launch of Vision 2030 in May 2006 
D. Minimize agricultural pollution

- $\quad$ Reduced use of pollutants

- Improved management of pollutants (variety of soil nutrient, IPM, organic farming etc)

E. Modify management of soil, water and vegetation resources

- Water management

- Soil management

- $\quad$ Tillage practices

- Cover crops, green manures and improved fallows

- Fire management

- Crop and livestock diversity

- Co-managing livestock and wildlife

F. Modify farming systems to mimic natural systems

- Agroforestry and other integrated systems (capturing the environmental services that perennial trees, shrubs and grasses provide). These services include soil and water conservation, control of water flow, soil nutrient cycling, wind protection, and production of mulch - leaf litter, which helps against soil erosion;

- Improved fallows;

- Multistrata systems or complex home gardens or agroforestry.

These six strategies were used to frame the scoping study on ecoagriculture innovations in the following landscape mosaics.

\begin{tabular}{|cl|l|l|}
\hline \multicolumn{2}{|l|}{$\begin{array}{l}\text { Area/Landscape } \\
\text { Mosaic }\end{array}$} & District & Closest Urban Centres \\
\hline 1. & $\begin{array}{l}\text { Lari } \\
\text { Division }\end{array}$ & Kiambu & Kiambu and Nairobi \\
\hline 2. & Mathioya & Muranga North & Muranga, Nairobi, Ruiru, Othaya and Thika \\
\hline 3. & Ndakaini & Muranga South & Muranga, Nairobi, Ruiru and Thika \\
\hline 4. & Taita Hills & Taita & Wundanyi and Voi Townships \\
\hline
\end{tabular}

These four sites, three in the central highlands and one in the southern part (see Figure 1 indicating the four sites and their agroecological zone) of Kenya were chosen based on three main criteria. They are part of a landscape mosaic with a mix of land uses made up agriculture, urban and protected areas, and they are important for biodiversity and watershed services. 


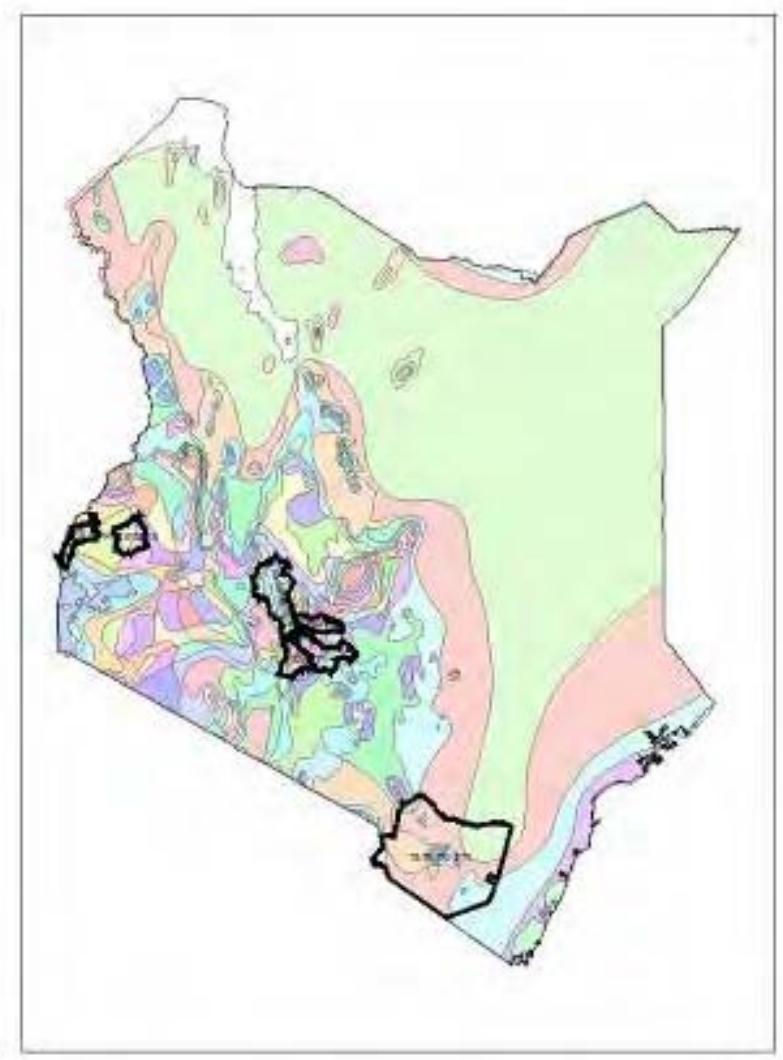

Figure 1: Study sites and their agroecological zone.

These landscape mosaics are adjacent to protected forests jointly managed by Kenya Wildlife Service (KWS) and Kenya Forest Service (KFS). They are sources of agricultural produce for adjacent urbanizing environments or heavily populated urban centres. Lari, Ndakaini and Muranga are adjacent to the critical Aberdares ecosystem and receive an average rainfall of $1800 \mathrm{~mm}$ each year. Taita Hills receive varied rainfall. All the sites are under intensive pressure from agricultural activities and adjacent forests have been reduced to fragments or completely deforested. In the Lari, Ndakaini and Mathioya ecosystems around the Aberdare range, the agricultural landscape mosaic areas include critical watersheds given that $50 \%$ of Kenya's hydropower production and $100 \%$ of Nairobi's water supply is dependent on the Aberdares ecosystem.

Continued river channel fragmentation and land use change lead to sedimentation and contamination risks that affect people further afield and threaten continued supply of water for hydropower production and urban water supply. Encroachment of adjacent forest fragments is affecting watershed services, limiting carbon sequestration potentials and biodiversity. These mosaics are not only important productive areas but are also important biodiversity habitats.

Due to the economic and ecological significance of these landscapes there have been various development interventions and initiatives. Most of these are aimed at promoting agricultural productivity, segregating agriculture from wildlife land uses, providing incentives for changes in land management, and promoting agroforestry and innovative farming approaches aimed at pollution control (e.g. organic farming). 


\subsection{Conceptual framework for ecoagriculture practices in Kenya}

Human and ecological systems are dynamic, interactive and interdependent. Ecosystems are complex adaptive systems that require flexible governance with the ability to respond to environmental feedback (Berkes and Folke, 1998). In this scoping study, we have looked at ecoagriculture innovations from sustainable ecosystems and human well being perspectives as we consider sustainability attributes like productivity (efficiency and profitability) adaptability, and equity (benefit sharing and governance) (FAO, 1993). It would also entail the maintenance of reliable, stable and resilient production over time, ensuring the access and availability of production assets and promoting the renewable use, restoration and conservation of local resources. Further, resilience ${ }^{4}$ in the described optimal social-ecological system is a desirable factor of the farming systems and practices, and where the costs and benefits are distributed in an equitable manner among the stakeholders, ensures both economic accessibility and cultural acceptability.

Smallholder farming systems in Kenya can be described through various perspectives. They have a temporal and spatial dimension where traditional and current conventional farming systems are influenced by the agro-ecology, social-cultural and economic aspects. Figure 2 describes the farming systems in Kenya in terms of the sustainability attributes and proposes the place of ecoagriculture practices.

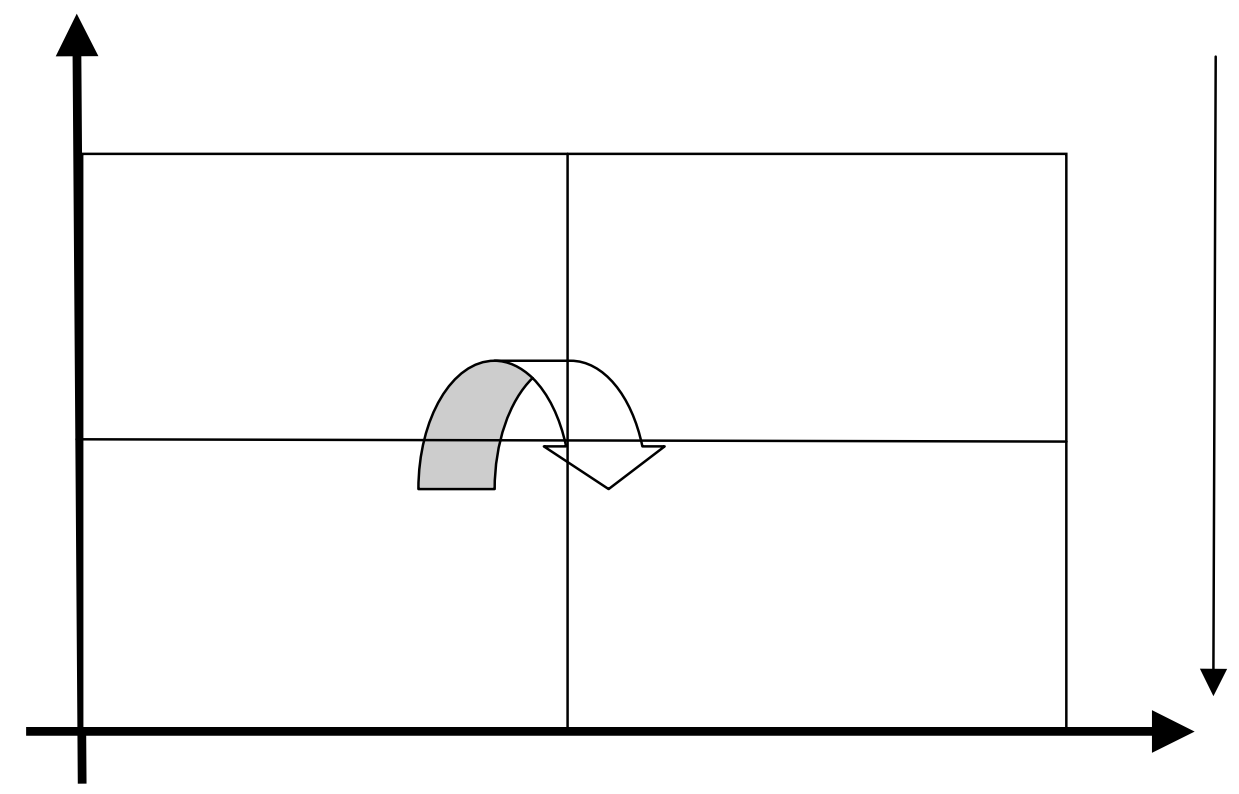

Figure 2: Developing a resilient farming system through Ecoagriculture practices.

\footnotetext{
${ }^{4}$ Resilience describes the capacity of an ecosystem to cope with disturbances, such as storms, pollution and erosion without shifting into a qualitatively different state. It also describes the ability of human communities to withstand and recover from stresses, such as environmental change or social, economic or political upheaval.
} 
Traditional farming systems were strongly embedded in the culture and traditions of the various tribal communities. Cultures evolved within an ecological context that dictated livelihood possibilities and these continue to shape agricultural practices in different landscape mosaics. The productivity of the traditional farming systems was low, but the great variety of biodiversity or coupled with the communities low population densities ensured their survival and reduced dependency. There were also low levels of nutrient mining and biodiversity loss. Some specific cultural norms and practices further ensured preservation and propagation of various genetic species. Though crop productivity per unit area was low, the diversity factor that ensured the availability of different edible products (based on seasonality) and therefore less dependency, hence maintaining a good measure of environmental integrity.

Based on Figure 2, the contemporary smallholder farmer is beset with a myriad of external and internal factors, resulting in natural resource degradation, nutrient mining. Productivity has declined, and dependency increased and many of the very poor smallholders have fallen into poverty traps of degradation with reduced capacity to overcome ecosystem shocks. Contemporary large scale farming evolved from colonial land allotments and consisted of the production of major food and cash crops, mainly on a monoculture basis, productivity in this production system is high but clearly dependent on a high input supply system. Further, it is also vulnerable to the market prices for both outputs and inputs.

Adopting ecoagriculture practices therefore calls for embracing principles that advocate for sustainability (Figure 2-fourth quadrant). Fostering local level collective action, linked to a multistakeholder governance process is another factor that can enable the achievement of landscape level outcomes for smallholder farmers. The study focused on observing to what extent the six strategies, based on biodiversity conservation and the management of ecosystem services were practised within the landscape mosaics, which in turn can increase or enhance the reliability, stability and resilience factors identified above.

\section{Methodology for the Scoping Study}

In order to promote uniformity in data collection, comparison of data across sites, and guide the scope of the study, a set of questions were formulated. The set of questions were organized into a matrix and included site characterization, biodiversity analyses, stakeholder analyses and exploration of existing/potential of financial and incentive mechanisms. Ecoagriculture strategies (described above) provided the reference point for farmer initiatives that were aimed at creating biodiversity reserves, provide habitat networks, increase agricultural productivity and reduce pollution, and modify farming systems to mimic natural systems.

Since the scoping study was also linked to a policy study, a component on stakeholder analyses, tenure and how policy and/or legislation shape adoption and scaling up of ecoagriculture innovations were also integrated as an important element of tooling the scoping study. The level of collective action and learning was also analyzed as it shapes scaling up of ecoagriculture innovations. The matrices were used for the inventory of ecoagriculture innovations and define policy provisions that shape their functioning.

The landscapes were treated as case studies and across the different sites an array of methodologies (questionnaire, observation and focus group discussions) were used. A one to two kilometre transects were used in the different sites. A start of each transect was left to the site teams to agree. Efforts were made to match transects with access/feeder roads since this was an effective way to move across the transect. 
In two sites Ndakaini and Taita Hills the location of each farm was geo-referenced using a handheld GPS (an example shown in Figure 7). These locations were overlaid onto an agro-ecological zone map of Kenya obtained from ILRI (ILRI 2007). Statistical analyses were done in STATISTICA (StatSoft 2001), after checking for normality using Shapiro-Wilk's test ( $p=0.05$ ). A total of 150 homesteads in the 4 landscape mosaics were visited as well as government institutions and non-governmental organizations (NGOs). An average period of 45 minutes was used to administer one questionnaire in each of the farms.

\section{Results}

Site specific summaries of ecoagriculture innovations are presented below in Table 1,2,3 and 4 using the frame for scoping and inventorying ecoagriculture innovation described in 2.1.

\subsection{Lari}

Lari Division is in Kiambu West, a district within the Central Province of Kenya, about $60 \mathrm{~km}$ west of Nairobi with a population of about 150,000 people. The division's altitude varies from 1800-2400 meters above sea level. A bi-modal rainy season is experienced from March-May (long rains) and in October- November (short rains). The major economic activity is farming although other practices like lumbering, stone mining are carried out on a very small scale. The higher part of the Division adjacent to Kereita forest is more agriculturally rich compared to the lower part that borders the Rift Valley (Figure 3).

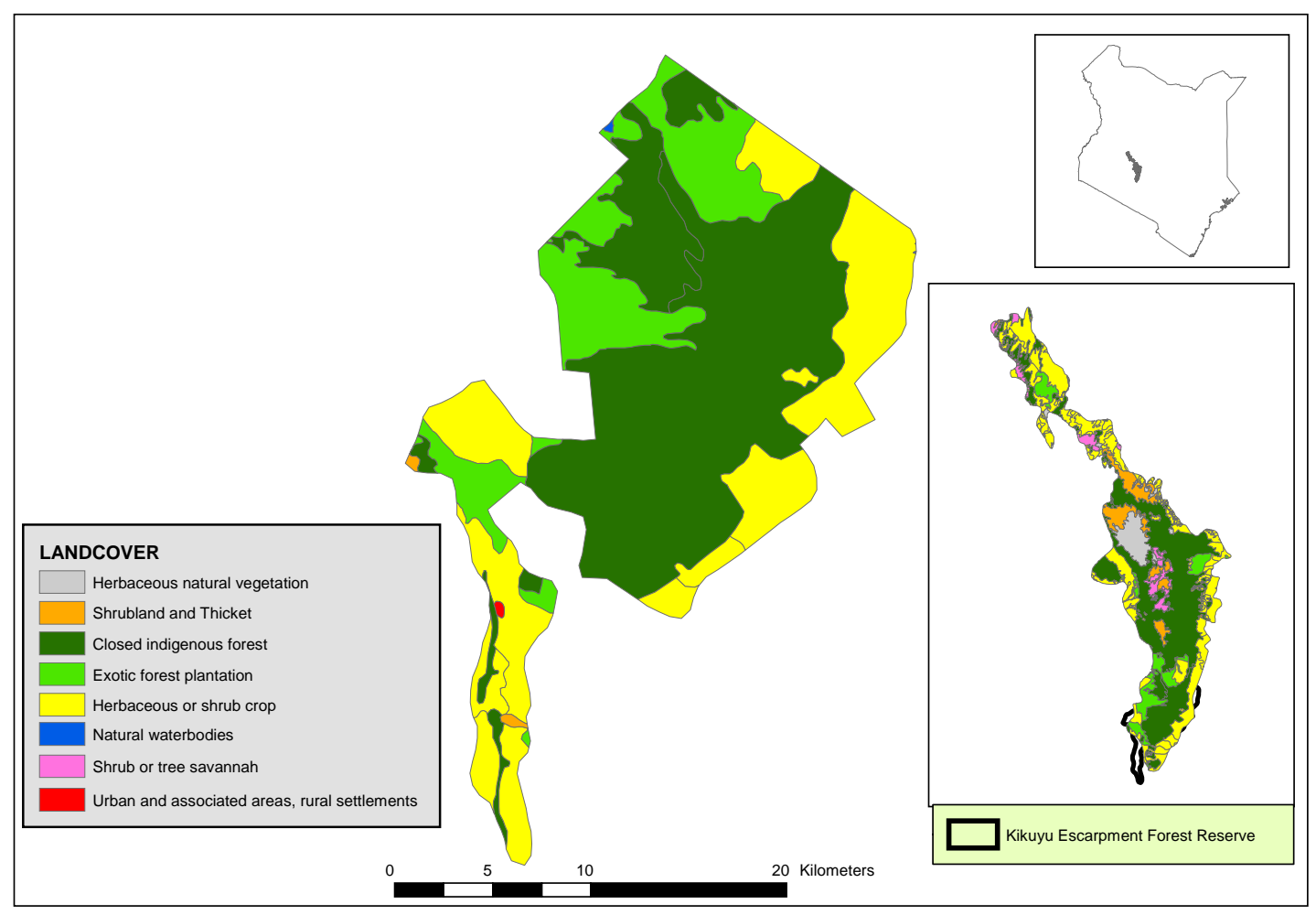

Figure 3: Map showing land use in Kikuyu Escarpment and Lari. 
Table 1: LARI - Benchmark strategies for ecoagriculture

\begin{tabular}{|c|c|c|c|c|c|}
\hline $\begin{array}{l}\text { Creating } \\
\text { biodiversity } \\
\text { reserves that } \\
\text { benefit local } \\
\text { communities }\end{array}$ & $\begin{array}{l}\text { Developing habitat } \\
\text { networks in non- } \\
\text { farmed areas }\end{array}$ & $\begin{array}{l}\text { Reduced land } \\
\text { conversion by } \\
\text { increasing farm } \\
\text { productivity }\end{array}$ & $\begin{array}{l}\text { Minimize } \\
\text { agricultural } \\
\text { pollution }\end{array}$ & $\begin{array}{l}\text { Modify } \\
\text { management of } \\
\text { soil, water and } \\
\text { vegetation } \\
\text { resources }\end{array}$ & $\begin{array}{l}\text { Modify farming } \\
\text { systems to mimic } \\
\text { natural systems }\end{array}$ \\
\hline $\begin{array}{l}\text { Farmers with large } \\
\text { pieces of land } \\
\text { have left some } \\
\text { fallow land, which } \\
\text { they consider } \\
\text { biodiversity } \\
\text { reserves. They } \\
\text { have varied } \\
\text { reasons for } \\
\text { leaving their land } \\
\text { fallow: fodder for } \\
\text { livestock, } \\
\text { improvement of } \\
\text { soil fertility, and } \\
\text { water drainage. } \\
\text { Smallholders also } \\
\text { cited benefits of } \\
\text { fallowing but } \\
\text { could not practice } \\
\text { it due to food } \\
\text { insecurity. }\end{array}$ & $\begin{array}{l}\text { None of the farmers } \\
\text { mentioned deliberate } \\
\text { creation of habitat } \\
\text { networks in non- } \\
\text { farmed areas as niches } \\
\text { for biodiversity. } \\
\text { Notably over } 60 \% \text { of } \\
\text { the interviewees had } \\
\text { some live fences and } \\
\text { birds were positively } \\
\text { cited as key species } \\
\text { using fences as their } \\
\text { habitat. Agro-forestry } \\
\text { is widely practiced with } \\
\text { the main purpose } \\
\text { being to enrich soil } \\
\text { humus and the wood } \\
\text { value of the trees. Fast } \\
\text { growing water thirsty } \\
\text { tree species are } \\
\text { planted along the edge } \\
\text { of the farmlands and } \\
\text { others have woodlots. } \\
\text { Indigenous trees } \\
\text { /shrub species planted } \\
\text { are Dobea torrida, } \\
\text { Castor, Bamboo, } \\
\text { Prunus and Olea } \\
\text { africanus }\end{array}$ & $\begin{array}{l}\text { Majority of farmers } \\
\text { practice cash crop } \\
\text { farming and mixed } \\
\text { farming. } \\
\text { Mixed farming is } \\
\text { mostly practiced by } \\
\text { those with a small } \\
\text { piece of land, in } \\
\text { order to enhance } \\
\text { maximum produce } \\
\text { for family use and } \\
\text { ensure the farm is } \\
\text { productive all year } \\
\text { round. This was } \\
\text { also attributed to } \\
\text { the traditional } \\
\text { farming systems } \\
\text { used and also the } \\
\text { unpredictability of } \\
\text { the weather. }\end{array}$ & $\begin{array}{l}\text { Most farmers had } \\
\text { some knowledge } \\
\text { on crop rotation } \\
\text { and practiced this } \\
\text { throughout the } \\
\text { year, aimed at } \\
\text { improved soil } \\
\text { fertility, disease } \\
\text { control and } \\
\text { reduction in the use } \\
\text { of chemicals. } \\
\text { About } 80 \% \text { of the } \\
\text { farmers interviewed } \\
\text { said that they } \\
\text { preferred farmyard } \\
\text { manure as opposed } \\
\text { to chemical } \\
\text { fertilizers as the } \\
\text { former improved } \\
\text { the soil structure } \\
\text { and fertility. Some } \\
\text { farmers pointed out } \\
\text { that manure } \\
\text { encourages friendly } \\
\text { organisms e.g. } \\
\text { worms that } \\
\text { improved the soil } \\
\text { fertility. }\end{array}$ & $\begin{array}{l}\text { Some farmers had } \\
\text { trenches, bamboo } \\
\text { stands, and water } \\
\text { pods in their farm } \\
\text { to collect rain } \\
\text { water. Planting of } \\
\text { napier grass and } \\
\text { agro-forestry were } \\
\text { mainly used to } \\
\text { prevent soil } \\
\text { erosion. }\end{array}$ & $\begin{array}{l}\text { Most farmers had } \\
\text { perennial crops in their } \\
\text { farms including napier } \\
\text { grass for fodder and } \\
\text { prevention of soil } \\
\text { erosion. Fruit trees e.g. } \\
\text { avocado, plums, pears } \\
\text { peaches, etc, were } \\
\text { also dominant. } \\
\text { Farmers in the upper } \\
\text { part of the division had } \\
\text { bananas both for food } \\
\text { and fodder. Others had } \\
\text { oat and other fodder } \\
\text { vegetation e.g. } \\
\text { caliandra. Those who } \\
\text { had a large potion of } \\
\text { land has left some fallow } \\
\text { areas, although they } \\
\text { were not developed. } \\
\text { Agroforestry was also } \\
\text { common although } \\
\text { there was little use of } \\
\text { indigenous trees. } \\
\text { Bamboo cultivation } \\
\text { both for water } \\
\text { conservation or } \\
\text { commercial purposes } \\
\text { was also practiced. }\end{array}$ \\
\hline
\end{tabular}




\subsection{Mathioya}

Mathioya Division in Murang'a district is situated on the eastern slopes of Nyandarua range and borders the Aberdares forest. Annual mean temperatures are between 10-23 degrees C, while rainfall ranges from 1000-2200 mm p.a in a bi-modal seasonal pattern. The land use is predominantly small scale tea, and mixed farming of coffee, maize, potatoes and agroforestry systems including cultivation of macadamia trees. The soils in the areas are mainly nitosols and andosols with pyroxenes, olivines, amphiboles and feldspars (Kamau, 1981). Rivers from the Mathioya ecosystem drain into the Tana river catchment area. The main rivers are South and North Mathioya and Godo River. However, various streams are also found in this area. In Mathioya scoping of ecoagriculture practices was undertaken in Wahundura and Kagongo-ini sub-locations (Figure 4).

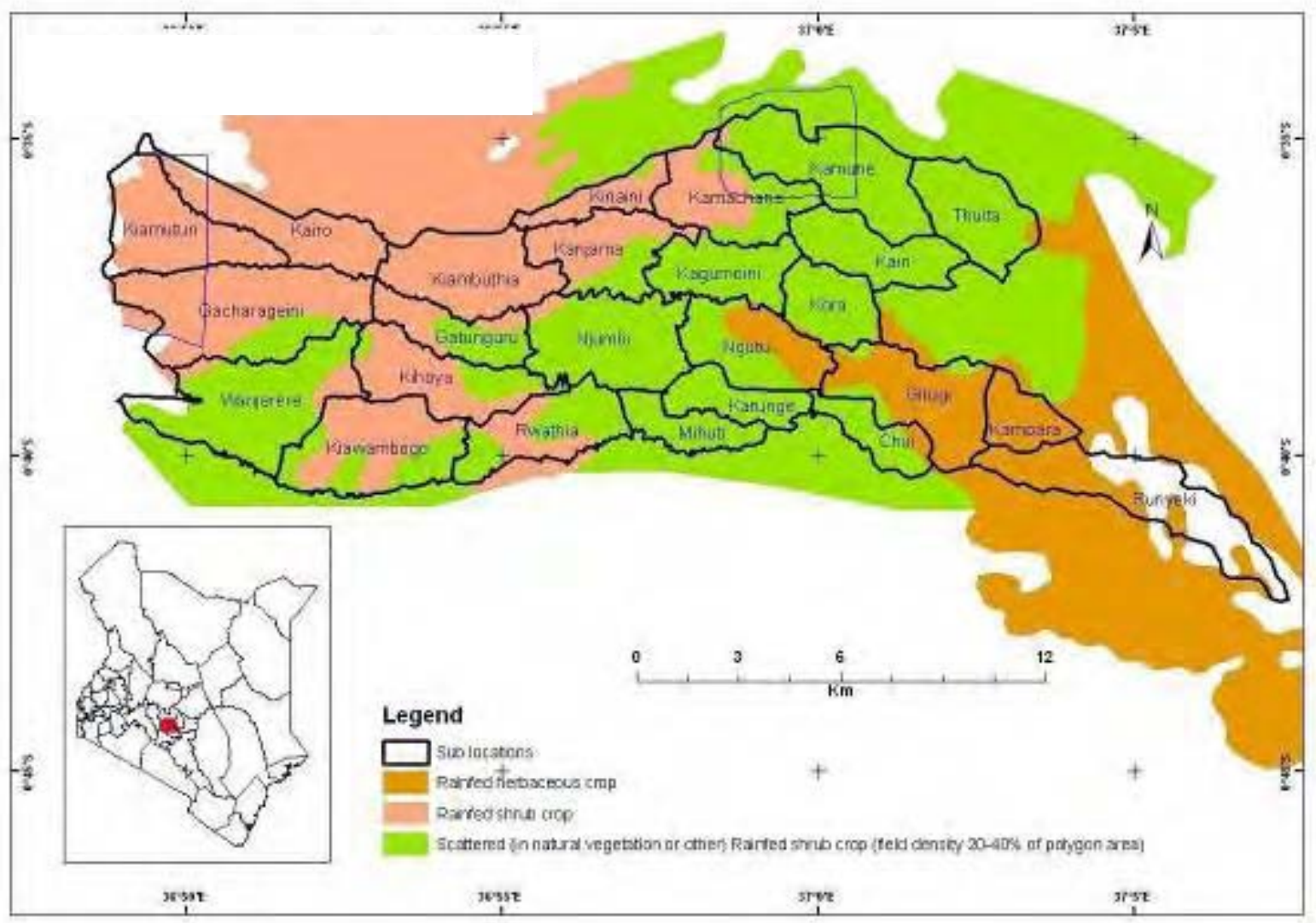

Figure 4: Map showing agricultural typologies in Mathioya, Muranga District. 


\begin{tabular}{|c|c|c|c|c|c|}
\hline $\begin{array}{l}\text { Creating biodiversity reserves } \\
\text { that benefit local } \\
\text { communities }\end{array}$ & $\begin{array}{l}\text { Developing } \\
\text { habitat } \\
\text { networks in } \\
\text { non-farmed } \\
\text { areas }\end{array}$ & $\begin{array}{l}\text { Reduce } \\
\text { land } \\
\text { conversion } \\
\text { by increasing } \\
\text { farm } \\
\text { productivity }\end{array}$ & $\begin{array}{l}\text { Minimize agricultural } \\
\text { pollution }\end{array}$ & $\begin{array}{l}\text { Modify } \\
\text { management } \\
\text { of soil, water } \\
\text { and } \\
\text { vegetation } \\
\text { resources }\end{array}$ & $\begin{array}{l}\text { Modify farming } \\
\text { systems to } \\
\text { mimic natural } \\
\text { systems }\end{array}$ \\
\hline $\begin{array}{l}\text { Efforts have not been made to } \\
\text { create biodiversity reserves. } \\
\text { The adjacent Aberdares } \\
\text { National Reserve is a source of } \\
\text { conflict between wildlife and } \\
\text { agriculturalists. In the recent } \\
\text { past, the Human-Wildlife } \\
\text { conflicts, have been mitigated } \\
\text { through the fencing of the } \\
\text { Aberdares national park. Non- } \\
\text { farmed areas and the intensive } \\
\text { agroforestry system provide } \\
\text { habitat and stepping stones for } \\
\text { wildlife. Trees planted are both } \\
\text { exotic and indigenous: } \\
\text { Eucalyptus saligna, Cordia spp, } \\
\text { Ficus spp, Moringa spp, Croton } \\
\text { spp, Grevillia robusta. The } \\
\text { number of birds and insects is } \\
\text { high given its adjacency to the } \\
\text { Aberdares ecosystem. }\end{array}$ & $\begin{array}{l}\text { Habitat } \\
\text { networks have } \\
\text { been formed } \\
\text { mainly for bird } \\
\text { species in } \\
\text { some farms } \\
\text { consisting of } \\
\text { various } \\
\text { woodlots. } \\
\text { Schools have } \\
\text { formed } \\
\text { environmental } \\
\text { and } 4 \mathrm{~K} \text { clubs. }\end{array}$ & $\begin{array}{l}\text { Agricultural } \\
\text { innovations } \\
\text { that reduce } \\
\text { land } \\
\text { conversion to } \\
\text { agricultural } \\
\text { land and } \\
\text { increase land } \\
\text { productivity } \\
\text { are mainly } \\
\text { strip farming, } \\
\text { agro-forestry } \\
\text { practices and } \\
\text { compost } \\
\text { farming. Farm } \\
\text { yard manure, } \\
\text { is mainly used } \\
\text { by farmers } \\
\text { and this } \\
\text { reduces on- } \\
\text { farm pollution } \\
\text { and increases } \\
\text { productivity. }\end{array}$ & $\begin{array}{l}\text { Farm yard manure, is } \\
\text { mainly used by farmers } \\
\text { and this reduces on-farm } \\
\text { pollution while increasing } \\
\text { agricultural productivity } \\
\text { within farms and } \\
\text { conservation of the } \\
\text { biodiversity. Some farmers } \\
\text { have also adopted organic } \\
\text { farming leading declining } \\
\text { use of inorganic fertilizers- } \\
\text { this is not to say that } \\
\text { fertilizers are not used. } \\
\text { Given that most farms are } \\
\text { under tea, tillage is not done } \\
\text { often therefore reducing } \\
\text { soil erosion. } \\
\text { Most of the inorganic } \\
\text { fertilizers are used in the } \\
\text { tea and coffee } \\
\text { farms. }\end{array}$ & $\begin{array}{l}\text { Soil } \\
\text { management } \\
\text { practices } \\
\text { consist mainly } \\
\text { strip farming, } \\
\text { which } \\
\text { controls soil } \\
\text { erosion, and } \\
\text { planting of } \\
\text { trees along } \\
\text { the edges of } \\
\text { farms. Agro- } \\
\text { forestry } \\
\text { practices are } \\
\text { common, } \\
\text { reducing } \\
\text { runoff. }\end{array}$ & $\begin{array}{l}\text { Agroforestry } \\
\text { systems and } \\
\text { afforestation } \\
\text { programmes are } \\
\text { mainly practiced } \\
\text { in this area and } \\
\text { most of the } \\
\text { agroforestry } \\
\text { species planted } \\
\text { consist of } \\
\text { gravellia robusta } \\
\text { trees. } \\
\text { Indigenous trees } \\
\text { have also been } \\
\text { planted on-farm } \\
\text { by some farmers }\end{array}$ \\
\hline
\end{tabular}

\subsection{Ndakaini/Muranga}

In Muranga South, the agricultural activities revolve around the Ndakaini Dam, which caters for $80 \%$ of Nairobi's water supply. Land use consists mainly of mixed cropping systems and upstream of the Ndakaini dam, is dominated by well developed agricultural land where tea occupies most of the farms interspaced with woodlots and boundary trees. Small plots of napier grass, maize and vegetables may be found on the larger holdings which contain stall fed dairy cattle. The exclusion of water services from the local communities by the Ndakaini dam owners (The Nairobi City Council) is a source of conflict. There appears to be a lack of concern for the conservation of the dam and its upstream tributaries, and land use cover change in the upstream areas will potentially lead to sediment loading and pollution of the Ndakaini reservoir.

In Muranga South, the scoping study was focused on the Ndakaini catchment, an area commonly referred to as the Thika river valley watershed, which is typical of the drainage systems flowing from the Aberdares East water tower. This is a critical watershed for the Masinga hydroelectric power plant. The Thika river watershed is supplied by the Chania River on the Southeast, Kimakia, Kiama, Gituika and Kayuyu Rivers. These rivers also drain Ndakaini Dam. Agricultural activity within the catchment is organized around the Ndakaini Dam (Figure 5). 
The dam is located at $0.32^{\circ}$ latitude south of the Equator and $36.8^{\circ}$ East longitude at a height of 1800 meters above sea level. It is one of the highest in the world. It occupies an area of $3 \mathrm{sq} \mathrm{km}$ with a circumference of $41.5 \mathrm{~km}$ and a depth of 60 meters when full.

Rainfall is variable and bi-modal. Amounts range from $600 \mathrm{~mm}$ to the East and over $2300 \mathrm{~mm}$ to the Northwest at the Aberdares foothills. The mean annual temperature ranges from $20^{\circ} \mathrm{C}$ at $1400 \mathrm{~m}$ above see level to $12.5^{\circ} \mathrm{C} 2500 \mathrm{~m}$ above see level.

Land use varies in the different agro-ecological zones. In the upper catchment area including the forest zone the land cover is bamboo and indigenous alpine trees typical of the Aberdares ecosystem. Cultivation or human settlement is sparse and totally prohibited beyond the forest boundary. Upstream of the dam is dominated by well-developed agricultural land where tea occupies most of the farms interspaced with woodlots and boundary trees. Small plots of napier grass, maize and vegetables may be found on the larger holdings, which contain stall fed dairy cattle. The lower catchment is occupied by smallholder farmers growing mainly tea, small patches of food crops (maize, English potatoes, vegetables etc) with dairy cattle, sheep and poultry. Most farmers have planted exotic trees such as Grevillea Robusta along their boundaries as hedges and keep woodlots of timber species such as wattle for fuel, charcoal and timber. Downstream of the dam, the land use pattern changes from tea farming to coffee through an interface of both and grown alongside maize and beans, sweet potatoes and other root crops. Most farms also grow a few fruit trees such as avocadoes and loquat. Napier grass is planted by all dairy farmers for fodder as well as for controlling sediment flow into the dam. Downstream, up to the confluence of Thika and Chania rivers the land use is dominated by large coffee plantations and small plots of maize/bean mixtures grown by resident labourers.

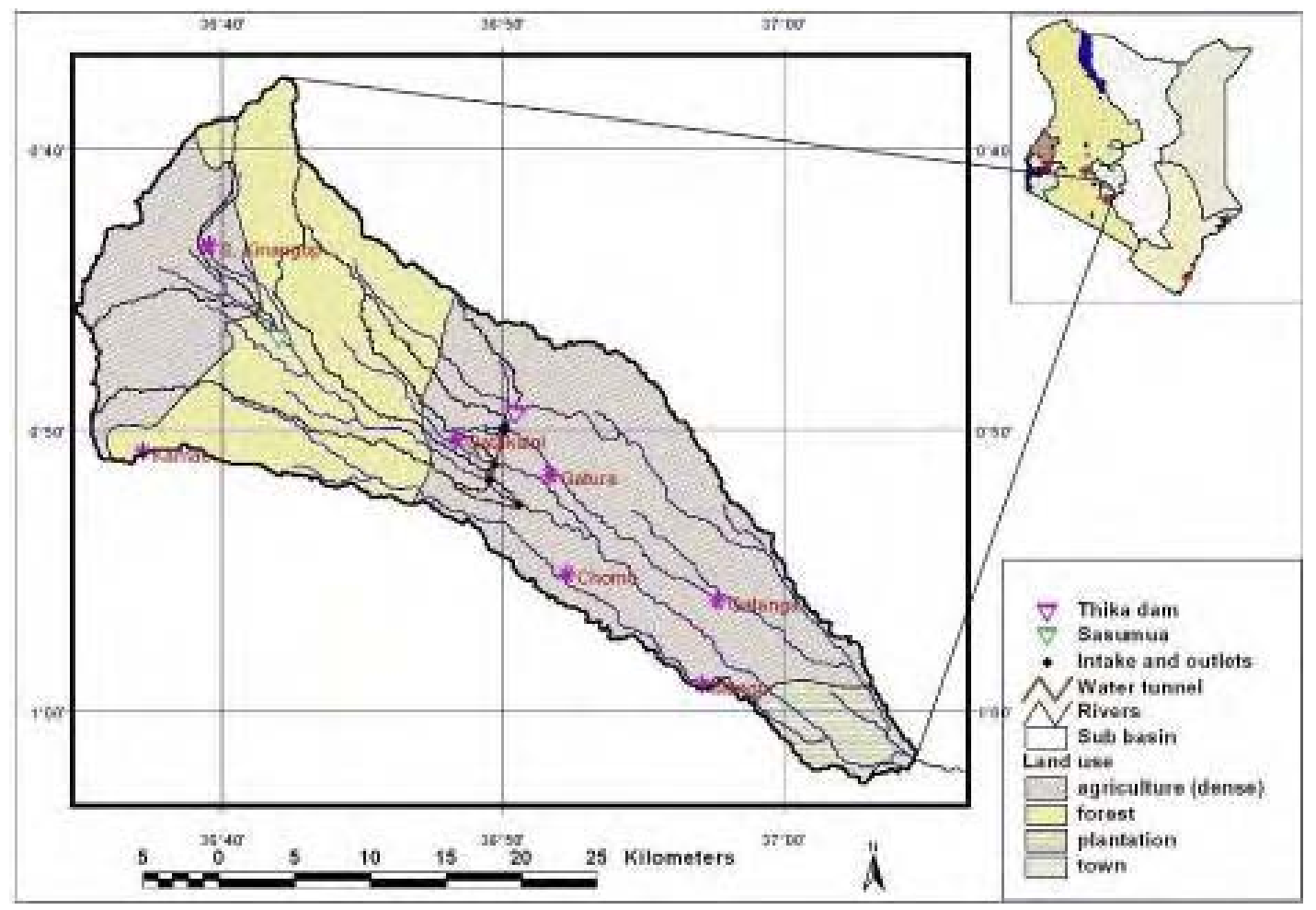

Figure 5: Map showing Land use in Ndakaini Catchment. 


\begin{tabular}{|c|c|c|c|c|c|}
\hline $\begin{array}{l}\text { Creating biodiversity } \\
\text { reserves that benefit } \\
\text { local communities }\end{array}$ & $\begin{array}{l}\text { Developing } \\
\text { habitat networks } \\
\text { in non-farmed } \\
\text { areas }\end{array}$ & $\begin{array}{l}\text { Reduce land } \\
\text { conversion by } \\
\text { increasing farm } \\
\text { productivity }\end{array}$ & $\begin{array}{l}\text { Minimize } \\
\text { agricultural } \\
\text { pollution }\end{array}$ & $\begin{array}{l}\text { Modify management } \\
\text { of soil, water and } \\
\text { vegetation } \\
\text { resources }\end{array}$ & $\begin{array}{l}\text { Modify farming } \\
\text { systems to } \\
\text { mimic natural } \\
\text { systems }\end{array}$ \\
\hline $\begin{array}{l}\text { There are no } \\
\text { deliberate efforts } \\
\text { made to create } \\
\text { biodiversity reserves. } \\
\text { However extensive } \\
\text { agroforestry systems } \\
\text { which form networks } \\
\text { act as biodiversity } \\
\text { habitats as well as } \\
\text { stepping stones for } \\
\text { biodiversity. } \\
\text { Extensive } \\
\text { agroforestry systems } \\
\text { and woodlots along } \\
\text { riparian areas are } \\
\text { useful biodiversity } \\
\text { areas. Fencing of the } \\
\text { adjacent Aberdares } \\
\text { National Reserves } \\
\text { has not reduced } \\
\text { losses of crops and } \\
\text { bird species on-farm. }\end{array}$ & $\begin{array}{l}\text { There are several } \\
\text { non-farmed zones } \\
\text { left aside not for } \\
\text { biodiversity but as } \\
\text { sources for timber, } \\
\text { wood fuel for } \\
\text { domestic and } \\
\text { industrial use as } \\
\text { well as controlling } \\
\text { land and mud } \\
\text { slides. The farmers } \\
\text { however } \\
\text { appreciated the } \\
\text { biodiversity } \\
\text { significance of } \\
\text { non-farmed areas } \\
\text { which together } \\
\text { with extensive } \\
\text { agroforestry } \\
\text { systems form } \\
\text { networks that join } \\
\text { the adjacent } \\
\text { Aberdares } \\
\text { ecosystem. }\end{array}$ & $\begin{array}{l}\text { Although mostly tea } \\
\text { and coffee farmers, } \\
\text { given their proximity } \\
\text { to Thika, Ruiru and } \\
\text { Nairobi townships } \\
\text { markets, they have } \\
\text { engaged in } \\
\text { macadamia, fruit and } \\
\text { agroforestry farming } \\
\text { to meet the high } \\
\text { demand for fruits, } \\
\text { macadamia and } \\
\text { timber in Nairobi, } \\
\text { Thika and Ruiru. Most } \\
\text { farmers have also } \\
\text { adopted organic } \\
\text { farming as a source } \\
\text { of income. To } \\
\text { increase productivity } \\
\text { farmers have also } \\
\text { adopted crop } \\
\text { rotational practices, } \\
\text { strip farming, } \\
\text { compost farming and } \\
\text { use of farm yard } \\
\text { manure. }\end{array}$ & $\begin{array}{l}\text { Farmers use farm } \\
\text { yard and compost } \\
\text { manure with an aim } \\
\text { to reduce pollution } \\
\text { of the Ndakaini } \\
\text { Reservoir. } \\
\text { Adoption of } \\
\text { organic farming, } \\
\text { and integrated } \\
\text { farming ensures a } \\
\text { self sustaining } \\
\text { system (rearing } \\
\text { goats, sheep and } \\
\text { rabbits provides } \\
\text { manure for crops, } \\
\text { wastes from } \\
\text { fodder are } \\
\text { composted, and } \\
\text { fresh produce sold. } \\
\text { This enable farmers } \\
\text { to acquire other farm } \\
\text { and household } \\
\text { produce. }\end{array}$ & $\begin{array}{l}\text { Farmers have } \\
\text { enhanced habitat } \\
\text { quality through } \\
\text { implementation of soil } \\
\text { and water } \\
\text { conservation } \\
\text { structures in } \\
\text { partnership with the } \\
\text { Nairobi City Water \& } \\
\text { Sewerage Company } \\
\text { which owns the } \\
\text { Ndakaini Reservoir. } \\
\text { Adjacent farmers are } \\
\text { provided with tree } \\
\text { seedlings for on-farm } \\
\text { planting as well as } \\
\text { planting in public land } \\
\text { e.g. along riparian } \\
\text { areas as well as along } \\
\text { the shores of the } \\
\text { Ndakaini Dam. }\end{array}$ & $\begin{array}{l}\text { Extensive } \\
\text { agroforestry } \\
\text { systems to a } \\
\text { certain extent } \\
\text { mimic the } \\
\text { adjacent } \\
\text { Aberdares } \\
\text { ecosystem. } \\
\text { Farmers } \\
\text { adjacent to the } \\
\text { Dam have } \\
\text { planted trees on } \\
\text { their farm next to } \\
\text { the dam and } \\
\text { these interface } \\
\text { with tea and } \\
\text { agroforestry } \\
\text { systems, which } \\
\text { subsequently } \\
\text { get } \\
\text { interconnected } \\
\text { with the } \\
\text { Aberdares } \\
\text { ecosystem } \\
\text { allowing } \\
\text { migration of } \\
\text { wildlife and bird } \\
\text { species. }\end{array}$ \\
\hline
\end{tabular}

\subsection{Taita Taveta}

Taita Taveta District, located in the Coast Province of Kenya, approx 200 kms northwest of the coastal town of Mombasa, has a population of 250,000 people with a density ranging from 3$800 / \mathrm{km}^{2}$. This huge variation is due to the varied rainfall and terrain, with the lower zones in the district receiving an average $440 \mathrm{~mm}$ of rain per annum and the highland areas receiving up to $1900 \mathrm{~mm}$. The altitudinal range rises from $500 \mathrm{~m}$ above sea level to almost 2,300 m above sea level at Vuria peak which is the highest (Brooks et al. 1998). $62 \%$ of the land area in the District is part of the Tsavo East and Tsavo West National Parks. The remaining 5,876 km ${ }^{2}$ consists of ranches, sisal estates, water bodies such as Lakes Challa and Jipe in Taveta. In addition, there are 48 forests that have survived on hill tops in the district, 28 of which are gazetted and are under government protection and management as Forest Reserves. In total, these forests occupy less than $100 \mathrm{~km}^{2}$ and range in size from $500 \mathrm{~m}^{2}$ to $2 \mathrm{~km}^{2}$. The Taita Hills forests form the northern most part of the biodiversity rich Eastern Arc Mountain forests ranging from Malawi through Tanzania (Brooks et al. 1998, Myers et al. 2000) and there are 13 plants and 9 animals taxa found only in the Taita Hills. (Beentje and Ndiang'ui 1988, Githiru 2003). These forests regulate the quality and quantity of water supply to the lowland areas, and are important for human, wildlife and agricultural activities. 
The district covers an area of 16,975 $\mathrm{km}^{2}$ of which $62 \%$ is within Tsavo East and Tsavo West National Parks. The bulk of the remaining $5,876 \mathrm{~km}^{2}$ is occupied by ranches, sisal estates, water bodies such as Lakes Challa and Jipe in Taveta (Figure 6).

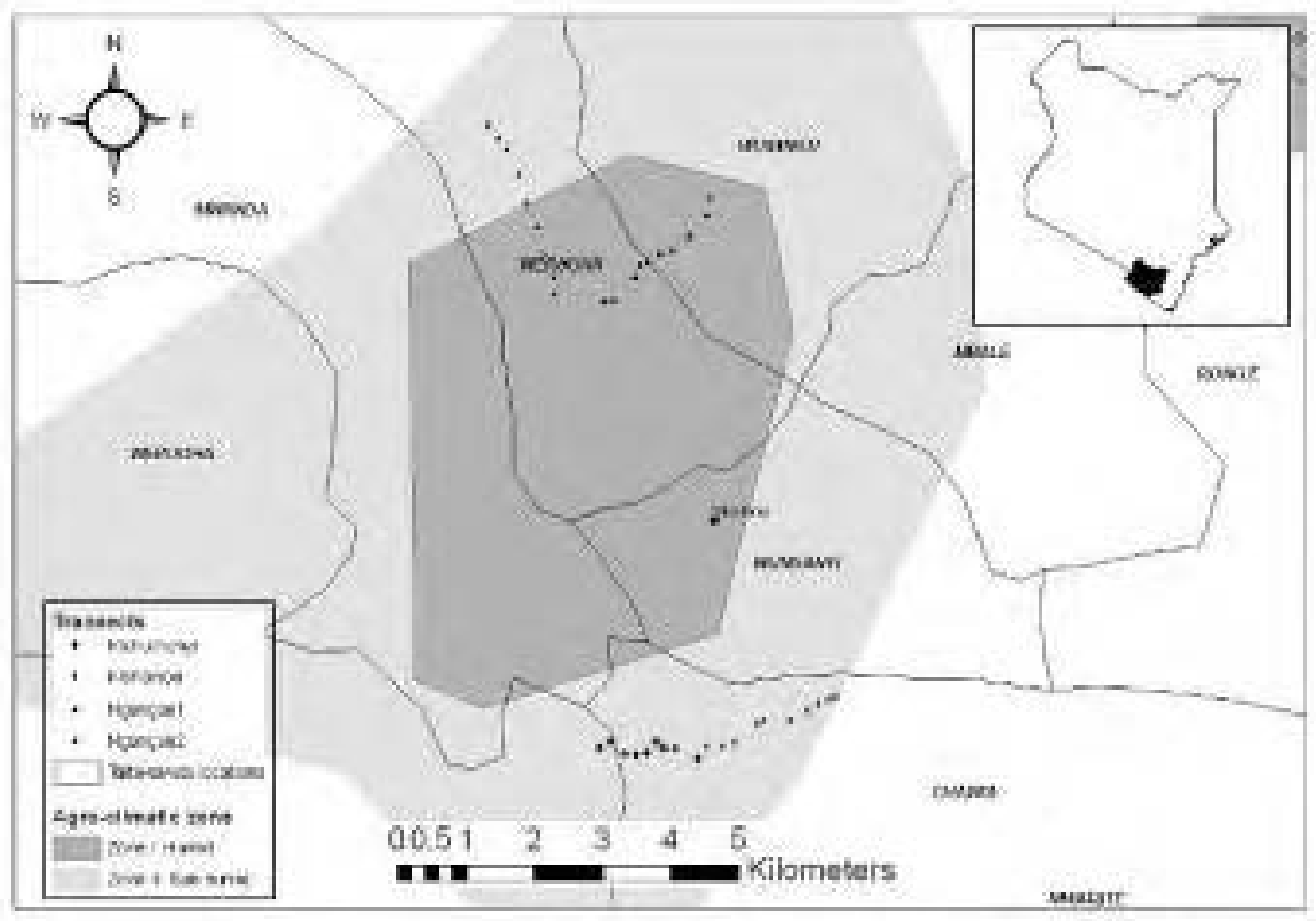

Figure 6: Map showing transects and agro-climatic zones in Taita Hills. 


\begin{tabular}{|c|c|c|c|c|c|}
\hline $\begin{array}{l}\text { Creating biodiversity } \\
\text { reserves that benefit } \\
\text { local communities }\end{array}$ & $\begin{array}{l}\text { Developing habitat } \\
\text { networks in non- } \\
\text { farmed areas }\end{array}$ & $\begin{array}{l}\text { Reduce land } \\
\text { conversion by } \\
\text { increasing farm } \\
\text { productivity }\end{array}$ & $\begin{array}{l}\text { Minimize } \\
\text { agricultural } \\
\text { pollution }\end{array}$ & $\begin{array}{l}\text { Modify } \\
\text { management of } \\
\text { soil, water and } \\
\text { vegetation } \\
\text { resources }\end{array}$ & $\begin{array}{l}\text { Modify farming } \\
\text { systems to mimic } \\
\text { natural systems }\end{array}$ \\
\hline $\begin{array}{l}\text { None of the farmers } \\
\text { mentioned combined } \\
\text { natural areas with } \\
\text { neighbours, or planned } \\
\text { their natural (non- } \\
\text { farmed) sites in } \\
\text { conjunction with them. } \\
\text { Notably however, two } \\
\text { farmers noted that } \\
\text { because their } \\
\text { neighbours had non- } \\
\text { farmed portions on their } \\
\text { farms, they had } \\
\text { increased attacks from } \\
\text { rodents and monkeys. } \\
\text { Farmers however } \\
\text { appreciate the potential } \\
\text { biodiversity advantages } \\
\text { including pollination, } \\
\text { erosion control, pest } \\
\text { control, and improved soil } \\
\text { fertility. }\end{array}$ & $\begin{array}{l}\text { Little evidence that current } \\
\text { land uses connected } \\
\text { natural habitat } \\
\text { networks of non-farmed } \\
\text { areas. Seven of the } 40 \\
\text { farms surveyed had natural } \\
\text { vegetation hedges ranging } \\
\text { between } 10 \text { and } 60 \mathrm{~m} \\
\text { length. However, } 28 \text { of the } \\
40 \text { farms had non-farmed } \\
\text { areas within them signalling } \\
\text { untapped potential for } \\
\text { creation of habitat } \\
\text { networks. Reasons for } \\
\text { leaving these areas fallow: } \\
\text { infertility of land, lack of } \\
\text { labour and provision of } \\
\text { wood products. Some } \\
\text { farmers had dams or fish } \\
\text { ponds signifying further } \\
\text { potential for creating small } \\
\text { natural habitats around the } \\
\text { water points. }\end{array}$ & $\begin{array}{l}\text { All surveyed farms } \\
\text { practiced mixed } \\
\text { cropping and/or crop } \\
\text { rotation. There were } \\
2-9 \text { different crop } \\
\text { species on each farm. } \\
\text { Maize and beans } \\
\text { were dominant crops } \\
\text { in } 28 / 40 \text { farms (70\%). } \\
\text { All but one of the } \\
\text { livestock-keeping } \\
\text { farmers practiced } \\
\text { zero-grazing. Only } \\
4 / 40 \text { farmers } \\
\text { mentioned used } \\
\text { traditional farming } \\
\text { techniques, viz., using } \\
\text { ash to control pests } \\
\text { based on traditional } \\
\text { knowledge. } \\
35 / 40 \text { farmers had no } \\
\text { sufficient land for } \\
\text { agriculture. }\end{array}$ & $\begin{array}{l}25 \text { of the } 40 \text { farmers } \\
\text { used pesticides on } \\
\text { their crops; } 29 \text { of } 40 \\
\text { used fertilizers on the } \\
\text { farm, while } 36 \text { of } 40 \\
\text { used organic manure. } \\
\text { Farmers seemed } \\
\text { unwilling to increase } \\
\text { inputs on the farm } \\
\text { because outputs were } \\
\text { generally low. } \\
\text { Chemical use was } \\
\text { associated with } \\
\text { vegetable farming, } \\
\text { which was not } \\
\text { common in the sub- } \\
\text { humid zone. Generally } \\
\text { there was little } \\
\text { evidence of } \\
\text { awareness of the } \\
\text { adverse effects of } \\
\text { chemicals on } \\
\text { biodiversity. }\end{array}$ & $\begin{array}{l}\text { Along each } \\
\text { transect, about } 50 \\
\% \text { of all farms used } \\
\text { some form of } \\
\text { irrigation and } 80 \\
\text { had some form of } \\
\text { soil conservation } \\
\text { activity-terraces or } \\
\text { trenches, and use } \\
\text { of trees to control } \\
\text { soil erosion. About } \\
50 \% \text { of all the } \\
\text { farms cover crops } \\
\text { for controlling soil } \\
\text { erosion. About } 50 \% \\
\text { of farmers } \\
\text { diversified their } \\
\text { livestock } \\
\text { production - poultry } \\
\text { rearing alongside } \\
\text { the cattle and } \\
\text { sheep/goats. }\end{array}$ & $\begin{array}{l}\text { Most farmers had } \\
\text { perennial crops on-farm - } \\
\text { avocado, macadamia } \\
\text { (Macadamia integrifolia), } \\
\text { guava (Psidium guajava), } \\
\text { passion, strawberry, } \\
\text { loquats (Eriobotrya } \\
\text { japonica), banana, } \\
\text { orange and mango. } \\
\text { About } 50 \% \text { also planted } \\
\text { napier grass as a cover } \\
\text { crop especially along } \\
\text { terrace edges to bolster } \\
\text { soil conservation. } \\
\text { About a fifth of each farm, } \\
\text { on average, was not } \\
\text { farmed. }\end{array}$ \\
\hline
\end{tabular}

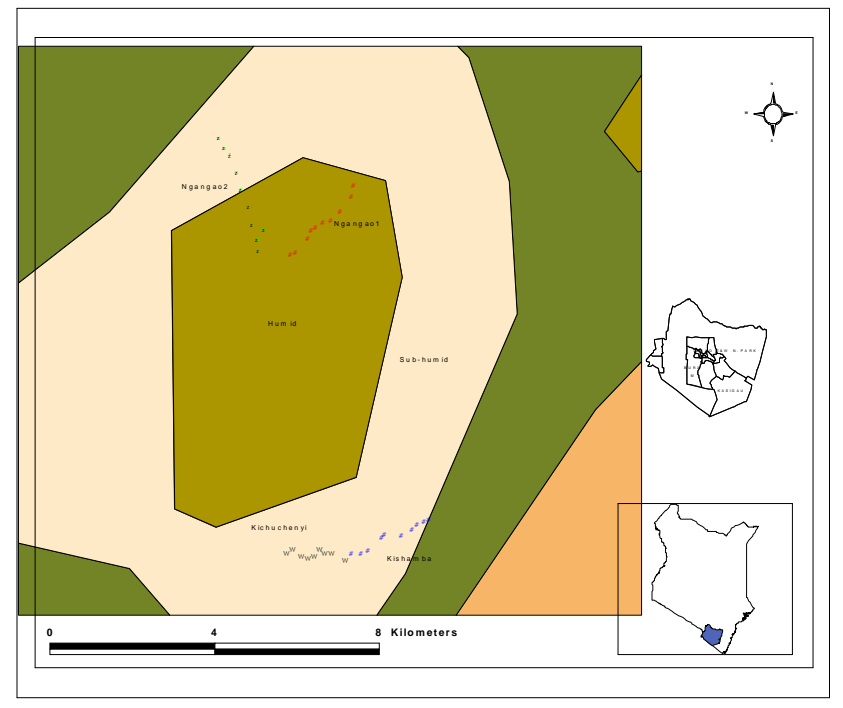

Figure 7: Map showing geo-referenced transects and farms in Taita Taveta District. 
In Taita Taveta the scoping team mapped non-farmed areas in four locations relative to land sizes (fig. 8). Although there were no significant differences in the proportions of the farms under different tree categories (ANOVA: Exotic trees: $F_{3,35}=0.7, p=0.56$; Fruit trees: $F_{3,35}=0.5, p=$ $0.67)$, there was a trend for indigenous trees $\left(\mathrm{F}_{3,35}=2.2, \mathrm{p}=0.11\right)$. There were lesser indigenous trees grown at Kishamba compared to the other areas (Figure 9). These differences were not significant when transects were combined into the agro-ecological zones for the three treecategories (t-tests: all p-values $>0.18$ ).

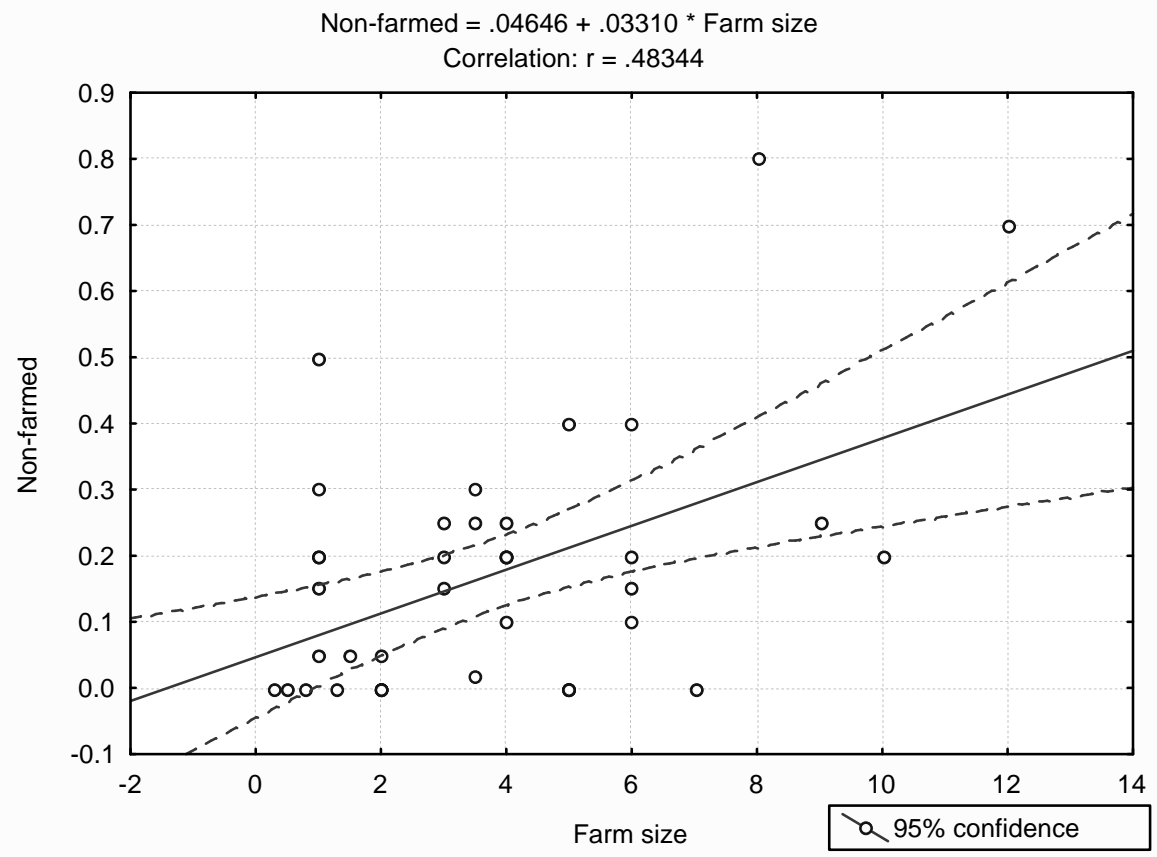

Figure 8: Plot of unfarmed areas against farm size in the Taita Hills landscape.

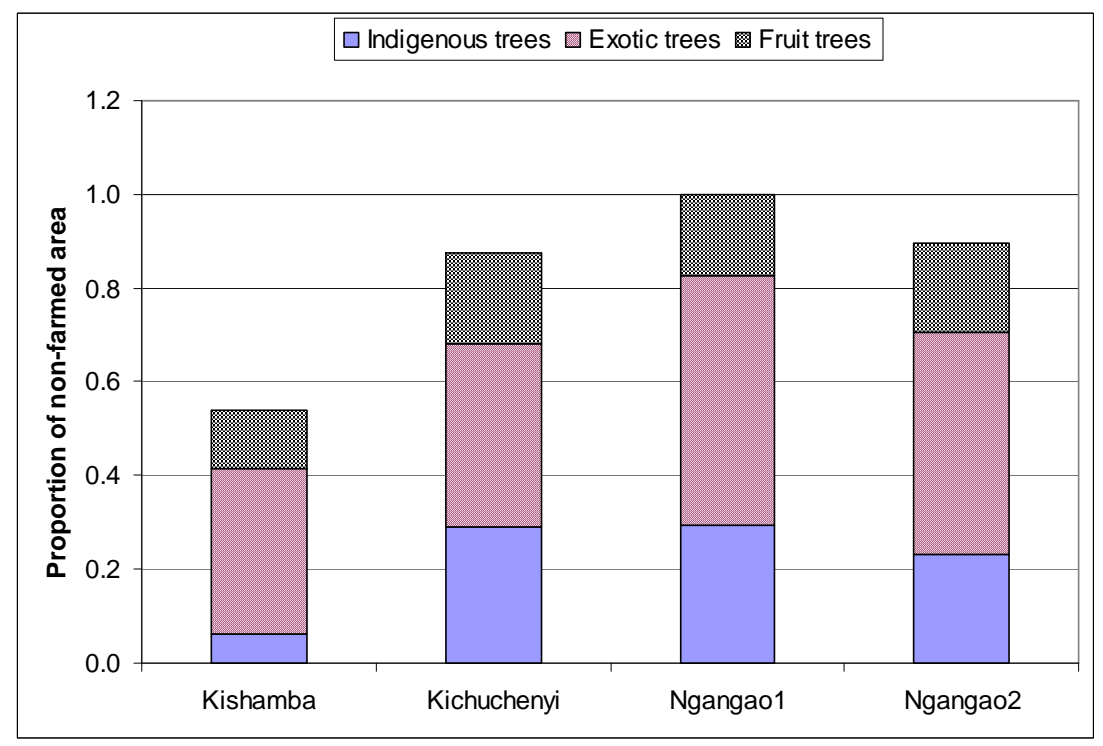

Figure 9: Mean proportion of the non-farmed area of the farms under different categories of trees. 


\subsection{Discussion of results}

Results show that farm sizes under the legal tenure of the interviewees differ across the different landscape mosaics, averaging 2.8 acres. Farmers with larger farms left larger portions unfarmed, while smallholders adopted agroforestry systems to fill this gap.

Agricultural innovations that increase productivity were adopted differentially across the different landscapes. This can be attributed to collective action and learning as farmers interact about farming techniques. However, it was observed that the farmers did not communally plan their natural (non-farmed) areas. Generally, in strictest terms, there were no deliberate efforts at creating biodiversity reserves. In some sites like Taita Hills, because farmers could not connect biodiversity advantages to the presence of natural biodiversity reserves, there was little deliberate effort towards developing habitat networks as biodiversity niches.

Agricultural intensification in all areas was moderate to low, involving only the use of pesticides and fertilizers; all farmers tilled their land by hand. In general, there was little evidence of awareness of the adverse effects of chemicals on biodiversity, and no allusion to any form of management of pollutants by any farmer. Most farmers adopted farming technologies like strip cropping between coffee and napier grass for livestock, agroforestry, terracing, mulching, tied ridges, trenches or cover crops (nappier grass and sweet potato) for soil conservation and increased productivity. All planted a variety of crops on their land, but only half of the ones with livestock also had poultry. Given the scale of farming in the different landscapes, farmers sold their produce in local markets through intermediaries.

The following provide a more in-depth analysis of a selection of the strategies for ecoagriculture in the four sites.

\subsection{Ecoagriculture strategies adopted at the sites}

\subsubsection{Modifying farming systems to mimic natural systems}

Agroforestry is included as an ecoagriculture strategy as it contributes (if conditions are appropriate) to improved incomes of farmers, enhanced food security and provides a refuge for biodiversity.

\subsubsection{Mixed agroforestry systems}

Typical agroforestry practices in the sites included the growing of mainly of fruit trees (avocado, mangoes, and passion); and Grevellia robusta, Acacia meanrsii (wattle tree) and exotics like eucalyptus saligna which are integrated with food (maize, cabbages, sweet potatoes, arrow roots and bananas) and cash crops (mainly coffee and tea) across the different landscape mosaics. Fruits are sold in urban markets and exported outside the country. Some species provide fodder for livestock. Trees are a source of woodfuel for domestic and industrial use (tea processing), and timber for the building industry in Nairobi.

In Ndakaini, Mathioya and Lari landscapes mosaics, agroforestry systems play important watershed functions and are stepping stones for biodiversity providing habitat for bird and animal species. Farmers reported that some birds and rodents have destroyed their crops.

Riparian zones have been turned into zones for woodlots especially of Eucalyptus saligna. These have been known to have hydrological impacts (e.g. eucalyptus are water thirsty trees consuming about 40 litres of water every day (ICRAF, 2007). 


\section{Scoping, motivational and constraining factors}

Given an average land sizes of 2.8 acres across the landscapes mosaics vis-à-vis high population growth rates (3\% per annum), one expects that there could be no areas for agroforestry as well as woodlots. However the adoption of agroforestry is attributed to the extension service provision, increased household and industrial demand, public pressure/perception that trees increase rainfall, corporate social responsibility, awareness creation (especially by Greenbelt Movement ${ }^{5}$ ), and high timber demand in adjacent urbanizing environments.

Most of the timber used in Nairobi is sourced from individual farmers in Ndakaini, Mathioya and Lari. The Government's policy on the ban on logging and processes and procedures on logging of agroforestry trees and subsequent timber transportation ensures that government effectively control sources of timber ${ }^{6}$. In Ndakaini, corporates like Kenya Breweries, Nairobi City Water and Sewerage Company (NCWSC) ${ }^{7}$, Delmonte Kenya Limited and government agencies like Kenya Forest Services have provided seedlings and participated in tree planting at plot and landscape levels.

Another agroforestry system is the Macadamia system on farms.

\subsubsection{Macadamia Systems}

Within Lari, Mathioya and Ndakaini smallholder farmers have grown macadamia trees because it is profitable with a ready market. Some farmers have started nurseries holding varied number and value of seedlings. A few farmers who have planted macadamia in large scale (5 acres) integrate passion fruit into the macadamia system. Other crops that they grow include sugarcane, bananas, maize, tea, potatoes, beans and maize. Farmers growing macadamia also engage in agroforestry system of fruit trees, Grevellia robusta and Eucalyptus saligna.

\section{Scoping, motivational and constraining factors}

Macadamia nuts are sold in local, regional and international markets. Two main buyers of macadamia nuts in Kenya are Kenya Nut and Farm Nut Companies. Macadamia systems adopt ecoagriculture innovations including use of manure, use of live fences (which are used as stepping stones for biodiversity), water conservation through the use of trenches, and mulching. Smallholder macadamia farming thrives because of the benefits that include inter alia: i) alternative source of income, ii) timber, poles and wood fuel, iii) soil conservation, iv) conservation of biodiversity, v) improved environmental aesthetics, and vi) improved food security. Macadamia systems are not without challenges: destructive pests, rodents, squirrels, bushbaby and birds; diseases and aphids; seasonal variability and suppressed undergrowth.

\subsubsection{Organic farming}

Organic farming ${ }^{8}$ is an innovation that in both short-and long-term time horizons can enhance biodiversity as well as improve farmers' livelihood systems.

\footnotetext{
${ }^{5}$ An organization run by 2004 Peace Laureate, Prof. Wangari Maathai-most of the agroforestry systems are attributed to her efforts-today we can say that Ndakaini, Mathioya and Lari are the best intensive and multifunctional agroforestry systems in the country.

${ }^{6}$ Many have argued that the government should not control farmers harvesting of agroforestry trees as government does not regulate how farmers harvest and transport vegetables to the market. In this paper we argued against this view simply because government does not grow vegetables but trees which farmers if left laissez faire could harvest and transport pretending that they have harvested from their own farms.

${ }^{7}$ NCWSC owns the Ndakaini Dam which supplies $80 \%$ of Nairobi's water demand-since it realized the threats of upstream land use change on sedimentation and pollution levels of the reservoir it has promoted and got involved in tree planting and agroforestry.

${ }^{8}$ Ecoagriculture strategies as discussed by Scherr, S. and Jeffrey McNeely (2003) and in some cases like in Ndakaini/South Muranga site, improvement typology as used by Rachel Hine and Jules Pretty (2006) for organic farming were modified and adapted to inform the framing of ecoagriculture innovations in critical landscape mosaics.
} 
The FAO/WHO Codex Alimentarius guidelines define organic agriculture as "a holistic production management [whose] primary goal is to optimise the health and productivity of interdependent communities of soil, life, plants animals and people”. The International Federation of Organic Agricultural Movements, with over 750 member organisations in 108 countries, defines organic agriculture as "a whole system approach based upon sustainable ecosystems, safe food, good nutrition, animal welfare and social justice.

Organic production therefore is more than a system of production that includes or excludes certain inputs” (Lampkin and Padel 1994, FiBL 2000, Scialabba and Hattam 2002, Caporali et al. 2003, Reganold 2004, FAO/WHO 2001, IFOAM 2006a, IFOAM 2002, quoted in Rachel Hine and Jules Pretty (2006)), thereby reduced pollution, promoting biodiversity as well as increasing productivity and subsequently income to farmers. Kenya had an estimated 180,000 ha under certified organic production. Walaga (2005) and Taylor (2005), quoted in Rachel Hine and Jules Pretty (2006). These are operating under no law or policy albeit government and stakeholders recognition of its significance. In Ndakaini Tugum Self Help Lifters Group, a womens group (Box 1) has adopted an integrated organic farming that involves growing of vegetables, kitchen garden goats, rabbits, agroforestry and tea growing. This is a self-sustaining system that generates extra income, reduces fertilizer use and soil erosion and promotes biodiversity (especially birds and small mammals). Farmers have formed common interest groups for organic farming.

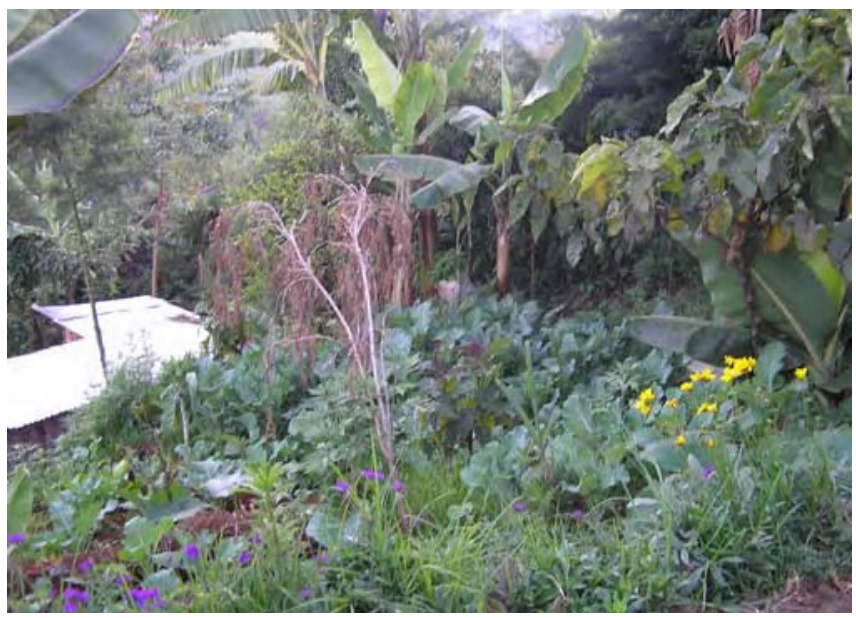

Tugum Self-Help Group (consisting of 15 members) was started in 2004 and is registered with the Ministry of Social Services. Its aim is to promote collective action and learning for the promotion, adoption and scaling up of organic farming in Ndakaini so as to reduce poverty. Organic farming was introduced by Kenya Women for Poverty eradication with some support from SACDEP and Plan International. The members pursue integrated organic farming, bench terracing, agroforestry (e.g. caster oil producing tree and fruit trees), water harvesting, composting manure and woodlots. Group members observed that birds have increased in their homesteads.

\section{Scoping, motivational and constraining factors}

Organic farming is widely adopted but not as extensive as it is in Thika District. A market for organic agricultural produce already exists in Juja. Demand for organic farming products comes mainly from Nairobi, Ruiru and Thika townships. Organic farming thrives because of the existing demand that is influenced by the perceived health benefits of consuming organically produced products. Demand for organically produced coffee, tea, vegetables and flowers in Europe, USA and Japan help sustain farmers' interest in organic farming. Organic farming is cheap given high poverty levels limiting fertilizer affordability. Despite the existence of the organic market in Juja, farmers still see market and marketing as insurmountable challenges. Kenya's Bridges Restaurant opposite Chester House exclusively sells organic food. The government is yet to recognize organic farming and therefore there is no legal regime to govern organic farming innovations. Adoption of organic farming innovations is evolving as Kenya National Network of Organic Farming (KOOF) continues to adopt a broad based awareness creation approach. A few farmers 
export their products to the European market. Organic farming presents opportunities including: i) ecological as well as human health benefits (fertilizers and chemicals are not used); ii) once certification systems are in place, the market will have been enhanced; iii) products are likely to gain premium leading to higher prices; and iv) innovations have the potential to enhance alternative treatment approaches for chronic diseases like diabetes.

\section{Conclusions}

Across the different landscape mosaics, the pursuit of ecoagriculture innovations is constrained by problemsthat are faced by smallholder farmers generally. These include insufficient land, animal/crop pests, and poor structural and market infrastructure. In Taita Taveta, farmers lamented the ever-declining rainfall and deteriorating fertility of the soil necessitating more and more fertilizer application. Seasons are also shifting making agriculture unpredictable.

Some farmers also mentioned an increased need for more pesticide application over time, which may be related to growing resistance of pests or reduced biological pest control agents. Lack of resources and poverty mean agricultural activities may not be improved without external help, especially availing seedlings and knowledge on best practices. These are likely to work against the pursuit of ecoagriculture technologies. Adoption of ecoagriculture innovations faces some challenges that have been expounded in the second paper on Policy Constraints facing Agricultural Development, Environmental Conservation and Poverty Reduction in East Africa.

It was observed that farmers only came together to organize themselves around an issue only if it has strategic significance for the community. It is only then that collective action and learning come forth. Seldom do farmers come together to exchange lessons and experiences with regard to adoption of particular agricultural technologies, which basically influenced by returns within a short-term planning horizon as well as the tradeoffs they have to make. Extension services and facilitation by the government was also cited as inadequate.

Most farmers recognized the value of agroforestry systems. Agroforestry systems are widely adopted but limited by lack of funds for purchasing seedlings. Adoption of agroforestry was largely based on their knowledge of the importance of trees on their farm for their wood-related needs and soil conservation. Other ecoagricultural friendly activities were mainly based upon them being cheaper than the alternatives, e.g., use of manure in lieu of fertilizer and use of ash instead of pesticides. Apart from trees, many people still did not take biodiversity to be of direct value to their farming and, if able, for instance considered it most preferable to use pesticides to control insects. Therefore, without directed and well targeted extension services for ecoagriculture, some strategies such as creating biodiverse resources, connecting and setting aside non farmed land, and minimizing agricultural pollution (apart from where there is a close and ready market for organic goods), will not be adopted.

Overall, the state of ecoagriculture innovations in the targeted landscapes can be said to be good even though they are spontaneous and largely ad hoc. Apart from tree-planting, which most interviewees considered highly, most of the positive aspects are directly related to livelihood improvements, and biodiversity objectives are indirectly achieved in a de facto manner because the option that protects or enhances biodiversity would be cheaper than an alternative option. Identified ecoagriculture innovations across the different landscape mosaics provide windows of opportunity for lesson learning as well as for scaling up. 


\section{Opportunities and Recommendations}

The current smallholder production systems in Kenya are characterized by mixed farming whereby one or two cash crops are grown often including maize, a major source of cash. Dairy is a component of the mixed smallholder farming and is composed of an improved cow breed or two per household amongst the better endowed small holders with a number of small stocks. Another category of smallholders are those with larger traditional stock and who mainly face hardships in getting enough fodder for their livestock especially where community land is unavailable or too degraded to yield the required sustenance. Poor terms of trade, increasing costs of production and land degradation resulting from nutrient mining; high fragmentation of land with subsequent reduction in productivity has created a high degree of dependency amongst the communities.

Fostering of collective action in livelihoods improvement has appealed to the communities but there also have been many cases of elite capture of the benefits accruing from collective action processes. The contemporary smallholder farmer is beset with a myriad of external and internal factors, resulting in natural resource degradation and nutrient mining. Productivity has declined, and dependency increased and many of the very poor smallholders have fallen into poverty traps of degradation with reduced capacity to overcome ecosystem shocks. Contemporary large scale farming evolved from colonial land allotments and consisted of the production of major food and cash crops, mainly on a monoculture basis. Productivity in this production system is high but clearly dependent on a high-input supply system. Further, it is also vulnerable to the market prices for both outputs and inputs.

Adopting ecoagriculture practices therefore calls for embracing principles that advocate for sustainability. Ecoagriculture, like other approaches such as sustainable land management ${ }^{9}$, call for a new paradigm in agriculture; where the call is to integrate biodiversity conservation in agricultural landscapes as an explicit objective that is linked to improved livelihoods. This integration enables desirable attributes for agriculture which include productivity, adaptability, equity, stability, resilience and reliability (FAO, 1993).

The recommendations to move from agriculture to ecoagriculture are described below.

\subsection{Market mechanisms and incentives for ecoagriculture approaches}

Exciting opportunities have emerged to reward farmers for improved land management. The landscape is the primary level where the actions of individual households intersect those of other users, and where scaling and governance issues come together. Landscape level studies provide insight into the costs and benefits of land management as they cascade from the level of the individual farmer to the landscape, and to the national level. As a result, increased awareness among policy-makers can trigger policy-restructuring, market-based incentives and institutional arrangements that support ecoagriculture practices. These are important for example, since tea, coffee and milk co-operative systems which had thrived between 1963 and 1980 have collapsed and in many cases farmers grow and market their products without much support.

\footnotetext{
${ }_{9}^{9}$ Sustainable land management which encompass ecoagriculture principles is in this sense defined as "a knowledge-based procedure that helps integrate land, water, biodiversity, and environmental management (including input and output externalities) to meet rising food and fibre demands while sustaining ecosystem services and livelihoods" (World Bank, 2006).
} 
Incentives need to be presented to farmers to take on and evolve ecoagriculture innovations. The emergent interest in payments for ecosystem services in Aberdares and Taita Taveta Landscapes are likely to deepen adoption and promotion of ecoagriculture innovations within agricultural landscapes as providers for much needed provisioning and environmental services. The World Agroforestry Centre (ICRAF) and the International Soil Reference Centre (ISRIC) are currently undertaking research on linking land use change to the quality and quantity of environmental services to provide solid scientific evidence to facilitate recognition of farmers as providers of environmental services, as well as how downstream service beneficiaries can reward such a provision. In the slopes of Aberdares, Starbucks and African Wildlife Foundation (AWF) with some involvement of the government have implemented a certification programme for coffee. The UTZ certified Fairview Estates produces highly quality coffee with minimal disturbances to the environment.

\subsection{Extension and information sharing on the benefits of ecoagriculture innovations}

Agroforestry activities, which are freely practiced can be improved and increased. While most farmers have trees on their farms, the quality of trees can be improved to include more indigenous trees and hedges. Extension and sharing of information on approaches such as integrated pest management (IPM) could promote greater diversity of species within farms. There can be strategic and deliberate efforts for improving the condition/structure of non-farmed areas.

\subsection{Encourage gender mainstreaming in the agricultural fold}

Most farmers across the different landscapes are mainly women and targeted training and capacity building can be provided to them through for example, women's groups to consider the tradeoffs, synergies and incentives for the adoption of ecoagriculture innovations and improved agricultural productivity.

\subsection{Collective action and scaling up}

Social and participatory processes leading to coordinated group action and learning would ensure that any gains made are entrenched in the community's way of life. At present farmers come together or take collective action to address challenges like marketing or raise funds to purchase inputs such as seedlings. These groups could include in their discussions, a sharing of ideas on ecoagriculture innovations. Farmer participation in exchange programmes will also be very useful in building the foundation for the scaling up of ecoagriculture innovations;

Scaling-up, defined as "bringing more quality benefits to more people over a wider geographic area more quickly, more equitably, and more lastingly” (IIRR, 2000), is an emerging research agenda, with great relevance to the spread of ecoagriculture practices. It is not easily done and involves the presence of a set of micro, meso, and macro factors. These factors include community participation, public support, and improvement of infrastructure, sound microeconomic environment, local capacity building by NGOs, and concerned governments. (Reij and Steeds 2003). It involves partnerships, promoting stakeholders participation and strengthening local innovation capacity (Franzel et al., 2001). It is also about reconciling diverse and often divergent local needs, working through a governance lens to enhance technology demand through negotiated solutions to landscape-level natural resource based problems. Bridging the micromacro gap is essential for successful scaling-up (van Reesch, 2007). 


\subsection{Landscape level analysis}

Farmers' decision-making to invest in ecoagriculture practices and foster spreading beyond the farm level is thus strongly governed by the policy- and economic environment. With the recent shift of attention to ecosystem services (MEA, 2005), exciting opportunities have emerged to change policies in favour of enabling sustainability of our farming systems, and study processes at landscape level. The landscape is the primary level where the actions of individual households intersect those of other users, and where scaling and governance issues come together. Landscape level studies provide insight into the costs and benefits of land management as they cascade from the level of the individual farmer to the landscape, and to the national level. As a result, increased awareness among policy-makers can trigger policy-restructuring, market-based incentives and institutional arrangements that support ecoagriculture practices. 


\section{References}

Beentje, H.J and N. Ndiang'ui. 1988. An ecological and floristic study of the Taita Hills, Kenya. Utafiti 1:23-66.

Berkes F and Folke C. eds. 1998. Linking social and ecological systems: management practices and social mechanisms for building resilience. Cambridge: Cambridge University Press.

Burke, I.C., C.M. Yonker, W.J. Parton, C.V. Cole, K. Flach, D.S. Schimel. 1989. Texture, climate, and cultivation effects on soil organic matter content in U.S. grassland soils. Soil Sci. Soc. Am. J. 53:800-805.

Brooks, T., L. Lens, M. De Meyer, E. Waiyaki, and C. Wilder. 1998. Avian biogeography of the Taita Hills, Kenya. Journal of East African Natural History 87:189-194. CBS. 2006. http://www.cbs.go.ke/. 05/09/2007.

Donald, P.F. 2004. Biodiversity impacts of some agricultural commodity production systems. Conservation Biology 18: 1-29)

FAO. 1993. Agro-ecological assessment for national planning: the example for Kenya. No 67, FAO Soils Bulletin, Rome, Italy: Food and Agricultural Organization of the United Nations.

FAO. 2007. http://www.fao.org/ag/agl/agll/prtaez.stm. 05/09/2007.

FAO. 2001. FAOSTAT, FAO Statistical Databases. Rome, Italy: Food and Agricultural Organization of the United Nations.

FAO. 1993. FESLM. World Soil resources Report No. 73. Rome, Italy: Food and Agricultural Organization of the United Nations.

Githiru, M. 2003. Endemic forest birds of the Taita Hills: using a model species to understand the effects of habitat fragmentation on small populations. DPhil. Thesis. University of Oxford, Oxford.

Groombridge, B, Jenkins M.D. 2002. World Atlas of Biodiversity: Earth's Living Resources in the $21^{\text {st }}$ Century. Univ. of California Press, Berkeley, CA.

Franzel S, Cooper P and Denning GL. 2001. Scaling up the benefits of agroforestry research: lessons learned and research challenges. Development in Practice 11: 524-534.

Hine R and Pretty J. 2006. Capacity Building Study 3: Organic Agriculture and Food Security in East Africa. http://www.unep-unctad.org/cbtf/events/dsalaam2.asp. accessed 020509.

Juma, Calestous and Lee Yee-Cheong. 2005. Innovation: applying knowledge in development to achieve the Millennium Development Goals. Millennium Project Government Printer. Nairobi.

ILRI. 2007. http://www.ilri.org/gis/. 05/09/2007.

Manning, R. 2002. Conservation Magazine Spring 2002 (Vol. 3, No. 2).

Kamau N.R. 1981. A study of mass movements in Kangema Murang'a District, Kenya. Department of Geology. University of Nairobi.

Kenya, Republic of. 2004. Strategy for Revitalizing Agriculture 2004-2014. Government Printer. Nairobi)

Kiers, E. Toby, Roger Leakey, Anne-Marie Izac, Jack Heinnemann, Erika Rosenthal, Dev Nathan and Janice Jiggins. 2008. Agriculture at a Crossroads. Science Vol 320 pp 320-321.

Leopold, L.B. ed. 1953. Round River: From the journal of Aldo Leopold. Oxford Press, New York.

MA (Millennium Ecosystem Assesment), 2005. Ecosystem and Human well-being: Synthesis. World Resource Institute, Washington DC.

Mbugua, D. 2002. Forst Outlook Studies. Kenya. Rome: Rome, Italy: Food and Agricultural Organization of the United Nations.

McNeely, J., and S. Scherr. 2003. Ecoagriculture: strategies to feed the world and save wild biodiversity. Island Press, Washington D.C.

Myers, N., R. A. Mittermeier, C. G. Mittermeier, A. B. da Fonseca, and J. Kent. 2000. Biodiversity hotspots for conservation priorities. Nature 403:853-858. 
Okoba BO. 2005. Farmers' indicators for soil erosion mapping and crop yield estimation in central highlands of Kenya. Tropical Resources Management Paper 62. Wageningen University, the Netherlands.

Okoba BO and de Graaff J. 2005. Farmers' knowledge and perceptions of soil erosion and conservation measures in the central highlands, Kenya. Land Degradation \& Development 16: 475-487.

Paul E.A, Paustian K, Elliott E.T, and Cole C.V. 1997. Soil Organic Matter in Temperate Ecosystems. CRC Press, New York.

Reardon T and Vosti RS. 1995. Links between Rural Poverty and the Environment in developing countries: Asset categories and Investment Poverty. World Development 23: 1495-1506

Reij C and Steeds D. 2003. Success stories in Africa's Drylands: Supporting Advocates and Answering Sceptics. Rome: Global Mechanism of the United nations Convention to Combat Desertification.

Richards, J.F. 1990. in Turner II, B.L. et al., Eds. The Earth as Transformed by Human Action. Cambridge Univ. Press, Cambridge, UK.

Scherr, S. and Jeffrey McNeely. 2003. Strategies to Feed the World and Save Wild Biodiversity. Island Press, Washington D.C.

StatSoft, I. 2001. STATISTICA (data analysis software system). in. StatSoft, Inc., Tulsa. FAO, Swift M.J and Ingram J.S.I., Eds., GCTE Report No. 13. Global Change and Terrestrial Ecosystems, Wallingford, UK. 1996).

Thomas D, Osbahr H, Twyman C, Adger N and Hewitson B. 2005. ADAPTIVE: Adaptations to climate change amongst natural resource-dependant societies in the developing world: across the Southern African climate gradient. Tyndall Centre Technical Report No. 35, Tyndall Centre, Norwich, UK.

Van Reesch E, 2007. Bridging the macro-micro gap: Micro-meso-macro linkages in the context of sector-wide approaches. In: A rich menu for the poor: Food for thought on effective aid policies. Effectiveness and Quality Department (DEK) - DGIS, the Hague, the Netherlands.

Von Braun, J. 2007. The World Food Situation. New driving forces and required actions. Washington DC: International Food Policy Research Institute.

World Bank, 2006. Sustainable Land Management. Challenges, opportunities, and trade-offs. The World Bank, Washington, DC.

World Resources Institute. 2005. The Wealth of the Poor: managing ecosystems to fight poverty. World Resources Institute. 


\section{WORKING PAPERS IN THIS SERIES}

1. Agroforestry in the drylands of eastern Africa: a call to action

2. Biodiversity conservation through agroforestry: managing tree species diversity within a network of community-based, nongovernmental, governmental and research organizations in western Kenya.

3. Invasion of prosopis juliflora and local livelihoods: Case study from the Lake Baringo area of Kenya

4. Leadership for change in farmers organizations: Training report: Ridar Hotel, Kampala, $29^{\text {th }}$ March to 2nd April 2005.

5. Domestication des espèces agroforestières au Sahel: situation actuelle et perspectives

6. Relevé des données de biodiversité ligneuse: Manuel du projet biodiversité des parcs agroforestiers au Sahel

7. Improved land management in the Lake Victoria Basin: TransVic Project's draft report.

8. Livelihood capital, strategies and outcomes in the Taita hills of Kenya

9. Les espèces ligneuses et leurs usages: Les préférences des paysans dans le Cercle de Ségou, au Mali

10. La biodiversité des espèces ligneuses: Diversité arborée et unités de gestion du terroir dans le Cercle de Ségou , au Mali

11. Bird diversity and land use on the slopes of Mt. Kilimanjaro and the adjacent plains, Tanzania

12. Water, women and local social organization in the Western Kenya Highlands

13. Highlights of ongoing research of the World Agroforestry Centre in Indonesia

14. Prospects of adoption of tree-based systems in a rural landscape and its likely impacts on carbon stocks and farmers' welfare: The FALLOW

Model Application in Muara Sungkai, Lampung, Sumatra, in a 'Clean Development Mechanism' context

15. Equipping integrated natural resource managers for healthy Agroforestry landscapes.

17. Agro-biodiversity and CGIAR tree and forest science: approaches and examples from Sumatra.

18. Improving land management in eastern and southern Africa: A review of policies.

19. Farm and household economic study of Kecamatan Nanggung, Kabupaten Bogor, Indonesia: A socio-economic base line study of Agroforestry innovations and livelihood enhancement.

20. Lessons from eastern Africa's unsustainable charcoal business.

21. Evolution of RELMA's approaches to land management: Lessons from two decades of research and development in eastern and southern Africa

22. Participatory watershed management: Lessons from RELMA's work with farmers in eastern Africa.

23. Strengthening farmers' organizations: The experience of RELMA and ULAMP.

24. Promoting rainwater harvesting in eastern and southern Africa.

25. The role of livestock in integrated land management.

26. Status of carbon sequestration projects in Africa: Potential benefits and challenges to scaling up

27. Social and Environmental Trade-Offs in Tree Species Selection: A Methodology for Identifying Niche Incompatibilities in Agroforestry [Appears as AHI Working Paper no. 9] 
28. Managing tradeoffs in agroforestry: From conflict to collaboration in natural resource management. [Appears as AHI Working Paper no. 10]

29. Essai d'analyse de la prise en compte des systemes agroforestiers pa les legislations forestieres au Sahel: Cas du Burkina Faso, du Mali, du Niger et du Senegal.

30. Etat de la recherche agroforestière au Rwanda etude bibliographique, période 1987-2003

31. Science and technological innovations for improving soil fertility and management in Africa: A report for NEPAD's Science and Technology Forum.

32. Compensation and rewards for environmental services.

33. Latin American regional workshop report compensation.

34. Asia regional workshop on compensation ecosystem services.

35. Report of African regional workshop on compensation ecosystem services.

36. Exploring the inter-linkages among and between compensation and rewards for ecosystem services CRES and human well-being

37. Criteria and indicators for environmental service compensation and reward mechanisms: realistic, voluntary, conditional and pro-poor

38. The conditions for effective mechanisms of compensation and rewards for environmental services.

39. Organization and governance for fostering Pro-Poor Compensation for Environmental Services.

40. How important are different types of compensation and reward mechanisms shaping poverty and ecosystem services across Africa, Asia \& Latin America over the Next two decades?

41. Risk mitigation in contract farming: The case of poultry, cotton, woodfuel and cereals in East Africa.

42. The RELMA savings and credit experiences: Sowing the seed of sustainability

43. Yatich J., Policy and institutional context for NRM in Kenya: Challenges and opportunities for Landcare.

44. Nina-Nina Adoung Nasional di So! Field test of rapid land tenure assessment (RATA) in the Batang Toru Watershed, North Sumatera.

45. Is Hutan Tanaman Rakyat a new paradigm in community based tree planting in Indonesia?

46. Socio-Economic aspects of brackish water aquaculture (Tambak) production in Nanggroe Aceh Darrusalam.

47. Farmer livelihoods in the humid forest and moist savannah zones of Cameroon.

48. Domestication, genre et vulnérabilité : Participation des femmes, des Jeunes et des catégories les plus pauvres à la domestication des arbres agroforestiers au Cameroun.

49. Land tenure and management in the districts around Mt Elgon: An assessment presented to the Mt Elgon ecosystem conservation programme.

50. The production and marketing of leaf meal from fodder shrubs in Tanga, Tanzania: A pro-poor enterprise for improving livestock productivity.

51. Buyers Perspective on Environmental Services (ES) and Commoditization as an approach to liberate ES markets in the Philippines.

52. Towards community-driven conservation in southwest China: Reconciling state and local perceptions.

53. Biofuels in China: An Analysis of the Opportunities and Challenges of Jatropha curcas in Southwest China.

54. Jatropha curcas biodiesel production in Kenya: Economics and potential value chain development for smallholder farmers

55. Livelihoods and Forest Resources in Aceh and Nias for a Sustainable Forest Resource Management and Economic Progress

56. Agroforestry on the interface of Orangutan Conservation and Sustainable Livelihoods in Batang Toru, North Sumatra.

57. Assessing Hydrological Situation of Kapuas Hulu Basin, Kapuas Hulu Regency, West Kalimantan. 
58. Assessing the Hydrological Situation of Talau Watershed, Belu Regency, East Nusa Tenggara

59. Kajian Kondisi Hidrologis DAS Talau, Kabupaten Belu, Nusa Tenggara Timur

60. Kajian Kondisi Hidrologis DAS Kapuas Hulu, Kabupaten Kapuas Hulu, Kalimantan Barat

61. Lessons learned from community capacity building activities to support agroforest as sustainable economic alternatives in Batang Toru orang utan habitat conservation program (Martini, Endri et al.)

62. Mainstreaming Climate Change in the Philippines

63. A Conjoint Analysis of Farmer Preferences for Community Forestry Contracts in the Sumber Jaya Watershed, Indonesia

64. The highlands: a shared water tower in a changing climate and changing Asia

65. Eco-Certification: Can It Deliver Conservation and Development in the Tropics

66. Designing ecological and biodiversity sampling strategies. Towards mainstreaming climate change in grassland management

67. Towards mainstreaming climate change in grassland management policies and practices on the Tibetan Plateau

68. An Assessment of the Potential for Carbon Finance in Rangelands

69. ECA Trade-offs Among Ecosystem Services in the Lake Victoria Basin

70. Le business plan d'une petite entreprise rurale de production et de commercialisation des plants des arbres locaux. Cas de quatre pépinières rurales au Cameroun

71. Les unités de transformation des produits forestiers non ligneux alimentaires au Cameroun. Diagnostic technique et stratégie de développement Honoré Tabuna et Ingratia Kayitavu

72. Les exportateurs camerounais de safou (Dacryodes edulis) sur le marché sous régional et international. Profil, fonctionnement et stratégies de développement.

73. Impact of the Southeast Asian Network for Agroforestry Education (SEANAFE) on agroforestry education capacity

74. Setting landscape conservation targets and promoting them through compatible land use in the Philippines

75. Review of methods for researching multistrata systems.

76. Study on economical viability of Jatropha curcas L. plantations in Northern Tanzania assessing farmers' prospects via cost-benefit analysis

77. Cooperation in Agroforestry between Ministry of Forestry of Indonesia and International Center for Research in Agroforestry

78. "China's bioenergy future. an analysis through the Lens if Yunnan Province

79. Land tenure and agricultural productivity in Africa: A comparative analysis of the economics literature and recent policy strategies and reforms

80. Boundary organizations, objects and agents: linking knowledge with action in agroforestry watersheds

81. Reducing emissions from deforestation and forest degradation (REDD) in Indonesia: options and challenges for fair and efficient payment distribution mechanisms

82. Mainstreaming climate change into agricultural education: challenges and perspectives

83. Challenging conventional mindsets and disconnects in conservation: the emerging role of eco-agriculture in Kenya's landscape mosaics 
The World Agroforestry Centre is an autonomous, non-profit research organization whose vision is a rural transformation in the developing world where smallholder households strategically increase their use of trees in agricultural landscapes to improve their food security, nutrition, income, health, shelter, energy resources and environmental sustainability. The Centre generates science-base knowledge about the diverse role that trees play in agricultural landscapes, and uses its research to advance policies and practices that benefit the poor and the environment.

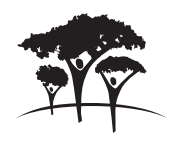

United Nations Avenue, Gigiri - PO Box 30677 - 00100 Nairobi, Kenya Tel: +254207224000 or via USA +1 6508336645 